Research Article

\title{
An evaluation of activities based on the use of the history of mathematics as a tool
}

\author{
Suphi Önder Bütüner \\ Yozgat Bozok University, Turkey
}

\begin{abstract}
In this study, teacher candidates were asked to evaluate activities designed with the use of the history of mathematics (HoM) as a tool in terms of the obstacles to the use of the HoM. A total of 12 activities which used the HoM as a tool were utilized in the study. The study group consisted of 40 teacher candidates who were first-year students in an elementary mathematics education program. The activities were used within the HoM course. The presentation and implementation of all activities took six weeks. Then, 40 teacher candidates completed written opinion forms, and 10 of them got interviewed. As the collected data were analyzed, teacher candidates' perceptions about whether each obstacle to the use of the HoM could emerge were identified. Afterwards, two different researchers examined the reasons underlying the identified perceptions. The findings showed that the activities used in this study could be used in mathematics classes and similar activities may stop the emergence of philosophical, student-related, stylistic and instructional preparation obstacles. . In the future, longer-term studies may be conducted with mathematics teachers and secondary school students with the activities used in this study. In this way, stronger evidence may be obtained about the effectiveness of using such activities in the instructional process.
\end{abstract}

Keywords: History of mathematics as a tool; Obstacle; Activity; Teacher candidate

Article History: Submitted 12 May 2020; Revised 11 July 2020; Published online 15 July 2020

\section{Introduction}

The idea that the history of mathematics (HoM) should be used as an instructional tool is not new. The earliest practical studies about the use of the HoM (McBride \& Rollins, 1977; Fraser \& Koop, 1978) started in the 1970s. In a 1989 declaration concerning evaluation standards for curriculum and school materials, the National Council of Mathematics Teachers emphasized the need for using the HoM in mathematics education. The declaration also stated that the goal of "learning to appreciate mathematics" may be achieved by using the HoM, therefore necessitating various student experiences in the scientific, historical and cultural development of mathematics (NCTM, 1989). In Turkey, historical content entered secondary school textbooks with the 2004 mathematics curriculum and the use of the HoM appears in the overall goals of mathematics education.

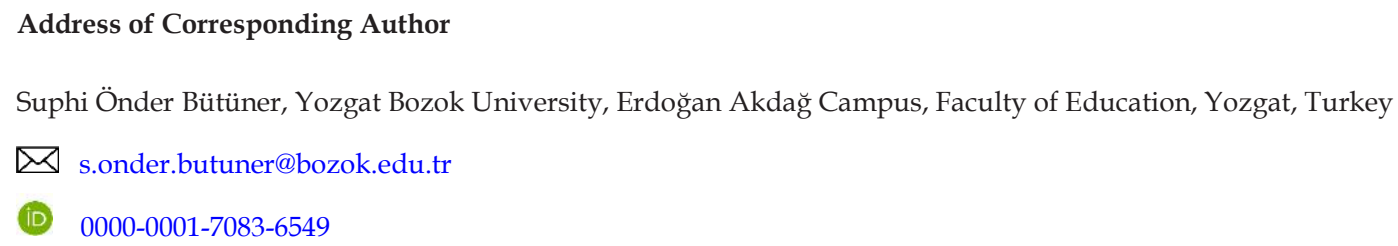

How to cite: Bütüner, S. Ö. (2020). An evaluation of activities based on the use of the history of mathematics as a tool. Journal of Pedagogical Research, 4(2), 139-164. 
In the literature, the use of the HoM has been encouraged by many researchers in mathematics classes (Fauvel, 1991; Fried, 2001; Gulikers \& Blom, 2001; Liu, 2003; Jankvist, 2009; Haverhals \& Roscoe, 2010; Wang, Qi \& Wang, 2017; Baki \& Gürsoy, 2018). The contributions of the HoM to the development of students' cognition and affect as well as teachers' subject area and pedagogical knowledge have been reported (Furinghetti, 2007; Huntley and Flores, 2010; Clark, 2012). Despite the mention of the positive effects of the HoM on students and teachers, the literature also cites many obstacles resulting from its misuse (Tzanakis \& Arcavi, 2002; Siu, 2007; Ho, 2008; Horton, 2011; Clark et al., 2018). Man-Keung Siu (2007) mentions sixteen obstacles to the use of the HoM in a study entitled "No, I do not use the HoM in my class, why?"

$>$ S1.I do not have enough time.

$>$ S2.History is not mathematics.

$>$ S3.How can I include questions about the HoM in my exams?

$>$ S4.It does not contribute to student grades.

$>$ S5.Students do not like it.

$>$ S6.Students take the HoM as history class and they hate history.

$>$ S7.Students find topics in the HoM as boring as those in mathematics.

$>$ S8.There is a shortage of materials in the HoM.

$>$ S9.I am not a professional mathematics historian. How, then, can I be sure about the accuracy and reliability of my practices?

$>$ S10.Teachers lack training in effectively using the HoM.

$>$ S11.Students do not have enough information on cultures to be able to evaluate the practices.

$>$ S12.The goal in mathematics is to solve difficult routine problems. Why should we go back in time then?

$>$ S13.It may confuse students by complicating mathematical concepts instead of clarifying them.

$>$ S14.Will the challenging task of reading original texts be useful?

$>$ S15.Will it lead to cultural chauvinism?

$>$ S16.Are there any studies showing that the use of the HoM improves student learning?

Previous studies have also shown a similarity to the obstacles mentioned above. Dickey (2001) studied the effects of the use of the HoM on eighth graders' learning and attitudes. The results showed that some students worried about scoring poorly on mathematics exams as a result of the HoM activities, falling behind the schedule and not being able to learn worthwhile knowledge. Lit, Siu and Wong (2001) conducted an experimental study using the HoM in mathematics instruction. They found that experimental students took more pleasure out of the learning process in the affective dimension, while their achievement level was lower than those in the control group in the cognitive dimension. The researchers commented that this may be explained by studying the relationship between the content taught to students and how they evaluate it. They added that test scores may be affected by knowing the accurate rules and formula, being able to correctly use them in questions and by student pace in solving a mathematical problem. They therefore argued that student test scores cannot explain the effects of the HoM on achievement. In a different study, Tözluyurt (2008) used the HoM activities with high school freshmen. All of their students preferred to carry out multiplication in the modern way, stating that multiplication in ancient Egypt had to be used by lower classes. They also stated that hieroglyph use was difficult and irrelevant to today's mathematics. Using the case study method, Kaye (2008) gave a video conference to teachers and 10 year old students from four schools on Babylonian mathematics. All of them had difficulty writing Babylonian numbers. Fraser and Koop (1978) asked the views of 39 mathematics teachers about certain the HoM instructional materials. The materials included a play on Thales' life and an article about conic history. Of the teachers, 14 stated that the play was time consuming and 6 stated that the article was the same. While 13 teachers argued that they did not 
possess the knowledge or experience to be able to use plays, 10 mentioned the same complaint about using articles. Equally noteworthy was that 36 teachers agreed that plays were inaccessible to them, while 32 stated that articles were inaccessible. Eleven teachers stated that they would not use plays in their classes and 17 stated that they would not use articles. Although teachers mostly held positive views about the activities, they also confessed that they would not use such materials in their instruction again. Panasuk and Horton (2012) investigated whether mathematics teachers used the HoM in their classes and their reasons why. Those who did not include the HoM in their classes listed their reasons as follows: lack of knowledge and skills on the use of the HoM, lack of resources, time limitations, mismatch between these materials and real exams. Gazit (2013) endeavored to identify the HoM knowledge level of mathematics teachers, and concluded that the level was rather low.

Tzanakis and Arcavi (2002) divided the obstacles before the use of the HoM in two categories: philosophical and practical obstacles. Haverhals and Roscoe (2010) treated Keung Siu's (2007) obstacles in the following categories: "philosophical obstacles (S1, S2, S12)", "student related obstacles (S5, S6, S7, S11)", "structural obstacles (S3, S4, S13, S14)", and "preparation for instruction (S8, S9, S10)". Another taxonomy of the obstacles to the use of the HoM put forward two different categories: "epistemological and method based obstacles" and "obstacles related to implementation-the nature of instruction" (Clark et al., 2018). Considered as a whole, all these researchers appear to support a common view regarding the obstacles to the use of the HoM. The results of previous research suggest that the obstacles to the use of the HoM include "the mismatch between historical content and the contents of current mathematics textbooks", "students finding it difficult and complex" and "mathematics teachers lacking the knowledge and experience in using the HoM". This study enabled teacher candidates to work on activities conducive to using the HoM as a tool and asked them to evaluate these activities in relation to whether they would create obstacles to the use of the HoM. The next part will explain the rationale of the study and its contributions to the field.

\subsection{Rationale for the Study}

As mentioned before, the literature mentions that there are certain obstacles to the use of the HoM despite its positive effects. While some studies report student benefits with the use of the HoM, others argue that the historical content is thought to be complicated, unnecessary and unpleasant by the students. Therefore, it is important to investigate how the HoM can be used in instructional environments. This may help prevent some of the problems emerging from the misuse of the HoM. This study aims to reveal whether the above-mentioned problems would still emerge as a result of using the HoM by a tool in line with teacher candidate views. The twelve activities in the study were prepared by considering the obstacles to the use of the HoM, and the following were ensured in order to prevent the emergence of the obstacles:

- It was ensured that the contents of activities were congruent with the contents of secondary and high school mathematics textbooks.

- The contents of activities were designed to teach a mathematical concept, rule or formula from current mathematics textbooks.

- Problem solutions aimed to teach interesting and different solution methods which present alternatives to current mathematics textbooks.

- Students were motivated by showing the role and importance of mathematics in society.

Another noteworthy aspect of the activities was that they encouraged students to discover mathematical rules and formula through paper cutting and pasting, decomposing and combining. It is believed that such use of the HoM may alleviate the obstacles mentioned before. This study may assist teachers and teacher candidates to use the HoM in their classes effectively. Also, it may guide future researchers when preparing HoM activities. The use of mathematics history as a tool and the activities used in this study are explained below. 


\subsection{Using the HoM as a Tool}

In this study, teacher candidates were asked to evaluate activities designed to use the HoM as a tool by considering the obstacles to doing so. The use of the HoM as a tool aims to improve not only students' knowledge of mathematical concepts but also their motivation towards learning mathematical concepts (Swetz, 1997; Ernest, 1998; Furinghetti \& Somaglia, 1998; Marshall \& Rich, 2000, Liu, 2003; NCTM, 2006). Jankvist's $(2009 a, b)$ views on the use of the HoM as a tool are given in Table 1.

Table 1.

The Use of the HoM as a Tool (Jankvist, 2009a,b)

1 The HoM is used to teach mathematical topics and concepts and to determine the problems experienced by students (epistemological obstacles)

2 The HoM is used to show students that even famous mathematicians made mistakes when solving problems and spent a long time on developing their solutions, and to make them braver and more persistent in the problem solution process

3 The HoM is used to enable students to solve problems by using different approaches and to learn a mathematical concept or relation

4 The HoM is used to make students compare new and old ways of solving problems or using symbols, and realize the advantages of new methods

5 The HoM is used by teachers to better teach mathematical topics and increase their students' motivation

6 The HoM is used to increase teachers' mathematics literacy levels

The twelve activities used in the study were designed in line with the use of the HoM as a tool. Appendix 1 shows the resources used in the preparation of the activities. It also includes information on them. The activities used in the study aimed to make students discover mathematical rules, formula and connections; solve problems; and understand the role and significance of mathematics in the society. The HoM was therefore used as a tool. While the students worked on the activities, they were supposed to construct their own new knowledge by using their previous experiences. For example, activity 12 asks students to use the areas of geometric objects when discovering the rule for sum of consecutive positive whole numbers. This is a previously learned piece of knowledge for the students. Therefore, they use existing knowledge and build upon it when constructing new knowledge. The activities expect students to discover mathematical rules and formula themselves. As can be seen, the instructional philosophy of the constructivist approach was adopted when preparing the HoM activities. Below, there is information about how activities 1, 3 and 6 are in line with the use of the HoM as a tool (how they can contribute to students' cognitive and affective development) and how obstacles to the use of the HoM may be prevented. In addition, activities 1, 3, 4, 8 and 9 are given in Appendix 2.

Secondary school students often confuse the rule of signs in multiplication. Therefore, when teaching the use of signage in multiplication in Grade 7, the alternative method of Jean-Robert Argand's (1768-1822) direction idea can be used (Figure 1). Jean-Robert Argand (1768-1822) was an amateur French mathematician. He published the Argand diagram, also known as complex numbers, with geometric interpretations. Let us assume that we are to multiply 1 and $i$ in this diagram. Both 1 and i have positive direction. As one proceeds from 1 to i counter-clockwise, the result will be positive. Therefore $1 \times i=i$. When 1 and $-i$ are being multiplied, 1 has positive direction, and $-i$ has negative. As one proceeds from 1 to -i clockwise, the result will be negative. Therefore $1 x-i=-i$ (Sip, 1990). The French mathematician Argand's idea is also true for the multiplication of two whole numbers. For example, below in the $3 \times(-2)$ operation, first 3 and -2 are shown in the 
vertical coordinate system. As 3 is in the $x$ axis and -2 is in the $y$ axis, and one proceeds from 3 to -2 (from the $x$ to the $y$ axis) clockwise, it is clear that the result will be negative. It is -6 . This activity provided students with an alternative method to remind them of the rule of signs in multiplication. It therefore serves the use of the HoM as a tool.
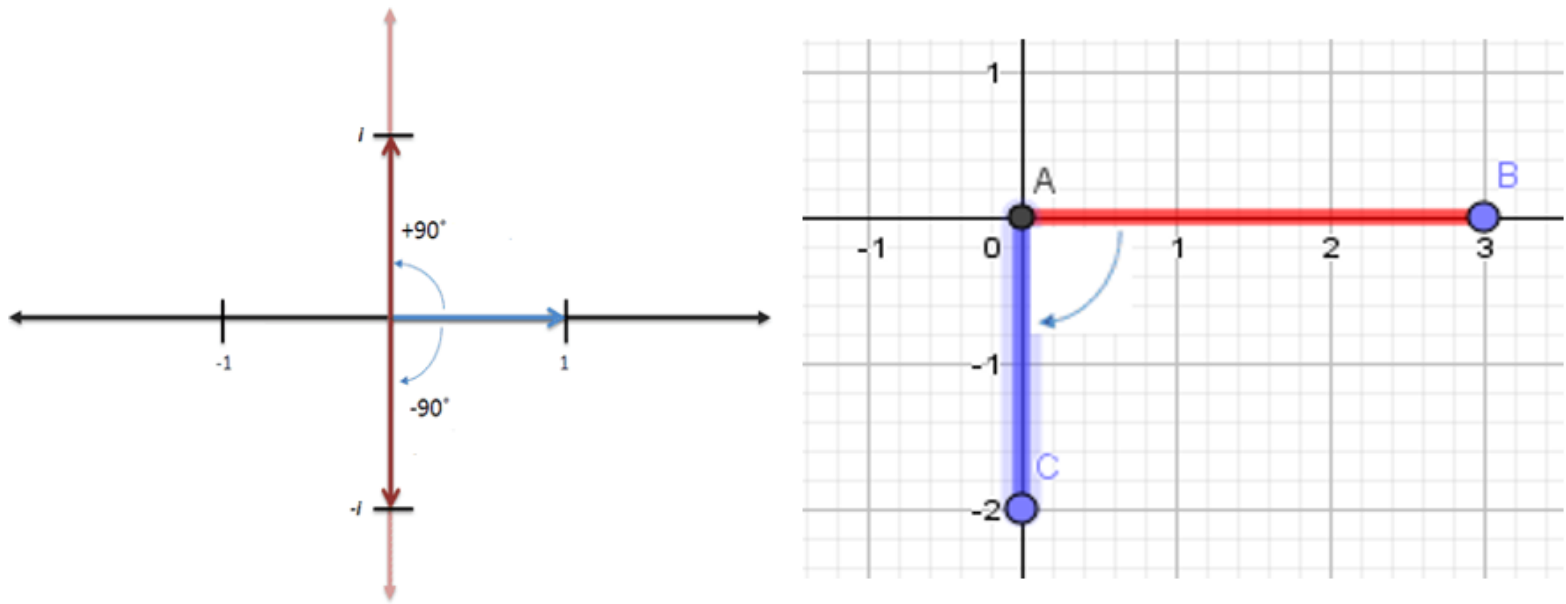

Figure 1. Jean-Robert Argand's rule of signs in multiplication

Activity 3 was prepared to help students conceptually learn the long form of $(a+b)^{3}$. In the ancient Chinese document titled Jiuzhang Suanshu, they reached the long form of $(a+b)^{3}$ by using the method of disintegrating and combining the parts (Dauben, 2007; Huntley and Flores, 2011). In this method, they calculated the volume of the geometric objects below (Figure 2) to find the open form of $(a+b)^{3}$. As the activity aimed to teach the students the long form of $(a+b)^{3}$, it is in line with the use of the HoM as a tool.

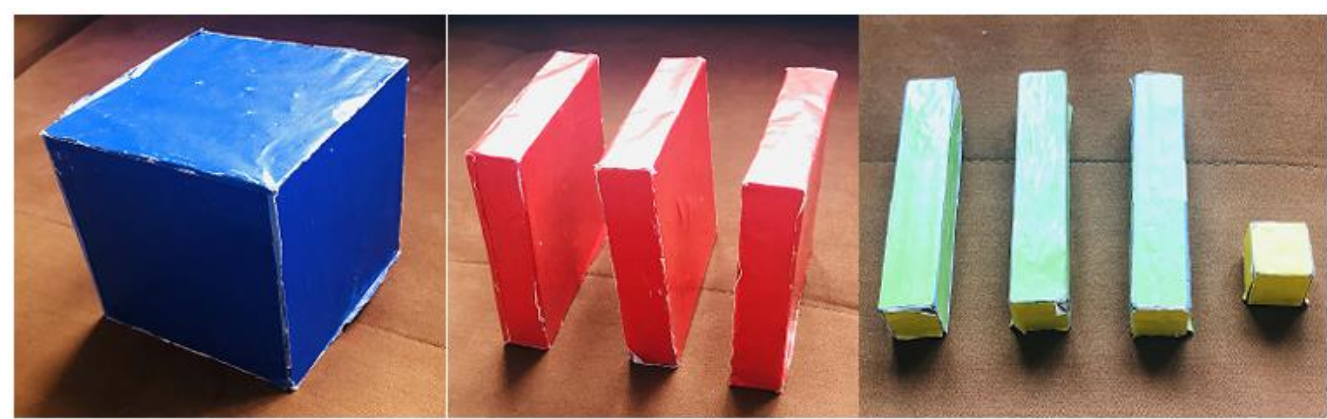

Figure 2. Geometric models used for the long form of $(a+b)^{3}$

In activity 6, students were presented with the length measurement units used in ancient times (Figure 3) and then they were asked to use these units to measure the length of various objects, compare their results and interpret the differences in the results. In this way, they were given an opportunity to understand the importance of using standard measurement units (the use of the HoM as a tool). The length measurement units used in ancient Egypt in 2500 B.C. are shown below (Dilke, 1993; Lumpkin, 1997a).

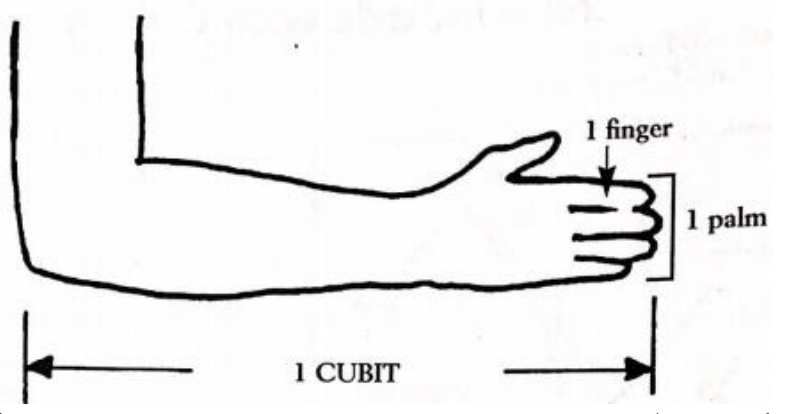

Figure 3. Length measurement units in ancient Egypt (Lumpkin, 1997a, p.8) 


\section{Method}

\subsection{Study Model and Participants}

In this qualitative case study, teacher candidates were asked to evaluate activities based on the use of the HoM as a tool with respect to the obstacles to the use of the HoM. The study group consisted of 40 teacher candidates who were first year students at a public university. The study sample was selected by using the purposive sampling method of easy access case sampling. Teacher candidates were attending the elementary mathematics education undergraduate program.

\subsection{Data Collection Process}

The study used 12 activities based on the use of the HoM as a tool. The activities were implemented in the HoM course, which is offered two-hour weekly during the first semester of the elementary mathematics education undergraduate program. The course aims to teach teacher candidates the contributions of different civilizations to mathematics and the historical development of mathematical concepts. The researcher is a lecturer of the HoM course. Ernest (1989) divides the roles of teachers into three categories: explainer, instructor, and facilitator. In the present study, the researcher assumed a facilitating quasi-experimental role (learning as the active construction of understanding). The introduction of the activities to the teacher candidates and their implementation took six weeks. Then, 40 teacher candidates completed written opinion forms, and 10 of them got interviewed. The questions on the written opinion form and interview questions were based on the obstacles mentioned in the literature against the use of the HoM. The question on the written opinion form was: "Below is a list of the obstacles to the use of the HoM (For example, "Students do not like the HoM"). Considering each of the 12 activities you worked on, do you think that the use of this type of activities in the mathematics class would lead to such obstacles? Explain your answer in detail. The participants were asked to provide a consolidated opinion.

\subsection{Data Analysis}

The literature mentions two types of content analysis. In deductive content analysis, themes emerge from the research questions or the theoretical framework of the study. In inductive content analysis, on the other hand, categories are derived directly from the text. Deductive content analysis is not commonly used, but is nevertheless beneficial for testing concepts, categories, theories or any conceptual structure in a new context. Deductive content analysis is similar to inductive content analysis in that it is applied in qualitative research and the data collection method aims to reach data saturation. The main difference between the two analytical techniques is that research in which deductive content analysis is applied usually has prior theoretical knowledge as the starting point. As such, the research questions are influenced by prior knowledge, and hence, affect the data collection stage.As in inductive content analysis, the reporting of results should be structured according to the identified concepts, categories and/or themes. Elo and Kyngas, (2008) and Hsieh and Shannon, (2005), stated that when testing an existing theoretical framework, the theoretical-deductive content analysis would work better. In the study, the data were analyzed in depth with respect to the main and sub themes identified in line with the theoretical framework of the study. In the analysis of the written and interview data, the main and sub themes were formed by using Haverhals and Roscoe's (2010) classification based on the 16 obstacles stated by Keung Siu (2007). Therefore, data were analyzed with deductive content analysis. The analysis was carried out by observing the stages mentioned in the literature (Vaismoradi, Turunen and Bondas, 2013; Bengtsson, 2016; Erlingsson and Brysiewicz, 2017). When the data from the written opinion form and interviews were analyzed, the written texts were read and re-read many times in order to gain an overall perspective on the data set. Following this, the written statements were underlined, and shortened in a way that would not change their meaning. Codes were then assigned to the shortened meaning units and suitable codes were organized 
together. The clusters thus formed were named by using the theoretical framework. Written texts were re-read repeatedly at different times to check the accuracy of the codes and whether the emerging codes belonged to the relevant main theme and sub theme. These were checked by a different researcher who specializes in qualitative research.

\subsection{Validity and Reliability}

The 12 activities designed were examined by two academics specializing in the HoM and two mathematics teachers with respect to the use of the HoM as a tool, their congruence with contents and objectives, and difficulty level. The activities were piloted on 8 teacher candidates and thus finalized. The written opinions of 40 teacher candidates were obtained, followed by interviews held with ten teacher candidates. The sub-themes and codes were created by analysing teacher candidates' written opinions. In order to obtain accurate findings, data were read repetitively to get an overall impression. The written texts were re-read at different times in order to check the accuracy of the coding and whether the resulting codes belonged to the relevant main and sub themes. Afterwards, these sub-themes and codes are confirmed with quotes taken from the interviews with 10 teacher candidates. The codings was reviewed by a specialist on the use of the HoM in classes and qualitative methodology. Both were confirmed by the specialist. Leading questions were not used in this study. Researcher maintained neutrality so as to not influence the participants' responses. All collected data were analyzed with clear and unbiased mind. Questions requiring explanation were used instead of short answer questions.

\section{Findings}

Teacher candidates worked on the 12 activities designed to use the HoM as a tool, and at the end of the study they provided written explanations about whether the use of the HoM as a tool would cause the obstacles mentioned in the literature and their reasons. Teacher candidates' written opinions about the emergence of philosophical obstacles when the HoM is used as a tool led to the emergence of four main categories: "The Contributions of the Activities to the Prevention of Philosophical Obstacles", "The Contributions of the Activities to the Prevention of Student-Related Obstacles", "The Contributions of the Activities to the Prevention of Stylistic Obstacles", "The Contributions of the Activities to the Prevention of Instructional Readiness Obstacles".

\subsection{The Contributions of the Use of the HoM as a Tool to the Prevention of Philosophical Obstacles}

Under this main category, there were three sub categories ("the activities do not cause time issues", "they are relevant to mathematics", "the use of history is necessary"). Figure 4 shows the sub themes and codes which are created by analysing teacher candidates' written opinions. Afterwards, these sub themes and codes are provided with quotes taken from the interviews with 10 teacher candidates. 


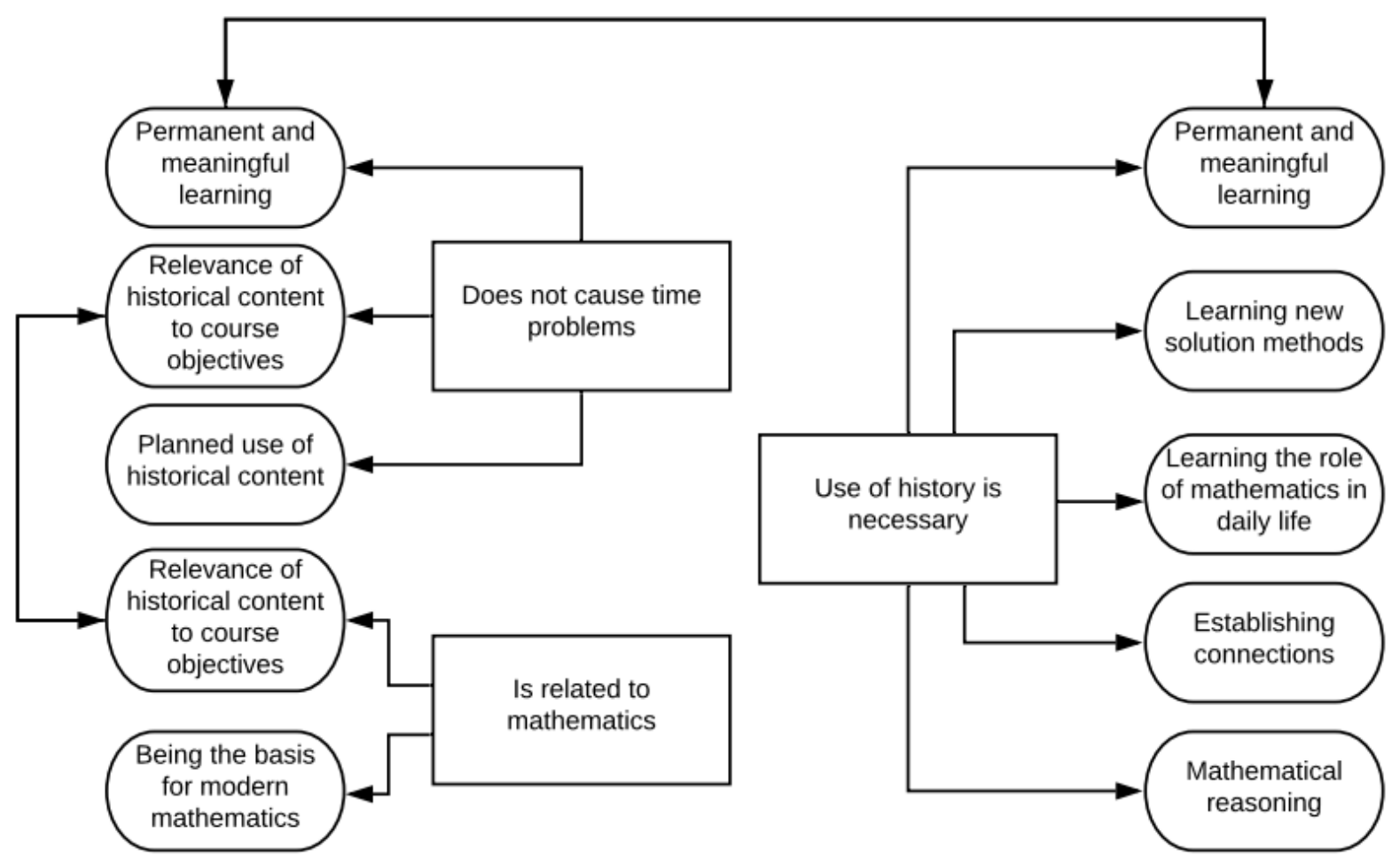

Figure 4. Subcategories and codes of the category "the contributions of the use of the HoM as a tool to the prevention of philosophical obstacles"

Teacher candidates emphasized that the activities were related to the course objectives ( $\mathrm{f}=39$ ), supported permanent and meaningful learning (number of teacher candidates, $f=34$ ) and the historical content was used in a planned way in the activities $(\mathrm{f}=29)$, and stated that such use of the HoM would not lead to time problems.

T2:HoM content concerns mathematics class. To illustrate, students finding the long form of $(a+b)^{3}$ with the Ancient Chinese method would not cause time loss because it is related to today's mathematics.

T7:The activities presented the HoM in relation to current mathematical topics. They used the concept of direction and Argand's solution of $1 x(-i)$ when teaching multiplication of whole numbers. If we relate the HoM to current topics, we won't lose time.

T11:Thanks to the activities, students can understand the underlying meaning of the rules and what they represent. Instead of spoon-feeding the rules, having students discover them in this way helps permanent learning. Therefore, this is no waste of time.

T4:As with the activities here, the use of materials in the classroom may steal some time, but this is negligible because the students see, understand, and explore. For instance, they reach the volume formula for the truncated square pyramid by using the method of cutting and disintegrating as in Ancient Egypt.

T21:The activities showed me that the right and planned use of the HoM does not lead to time loss. I mean, if you allocate a whole class hour to numbers in ancient Egypt, you may see the HoM as a waste of time. The activities here used the HoM in a planned way.

T30:The activities were all about current mathematical concepts and rules. We could've also seen historical things not mentioned in mathematics books. For example, we could've had samples of historical books, old representations. What is important is to use history with a plan, to manage our time in class.

According to the teacher candidates, as the activities were tied to the course objectives $(\mathrm{f}=38$ ) and included the bases of today's mathematics $(\mathrm{f}=12)$ they were relevant to mathematics. Interview opinions supporting this can be seen below. 
T14:If we only use history as old notations, representations, old numbers, problem solutions in ancient languages, of course everybody will think it is not mathematics but in our activities, we learned about the use of the HoM in teaching today's mathematical topics. If it is used well, history cannot be thought of as separate from mathematics.

T17:The activities were related to today's mathematics; therefore, if these activities are used, students and teachers will not think that history cannot be mathematics.

T9:Studies in the HoM form the basis of today's mathematics. In order to understand current mathematics, students must know its history.

T21: The past plays an important role in shaping today's mathematics. Therefore, the HoM is relevant to current mathematics.

Teacher candidates agree that the use of the HoM is necessary. They stated that the use of the HoM was necessary; the activities contributed to permanent and meaningful learning $(\mathrm{f}=39)$ and various different solutions $(\mathrm{f}=21)$; they helped students to understand the role of mathematics in daily life $(\mathrm{f}=18)$ and its relations with other disciplines $(\mathrm{f}=14)$; and they develop students' assumption skills $(\mathrm{f}=18)$.

T32:What is important in mathematics is to understand where the rules to be used in problem solutions come from and what they mean, rather than simple problem solution. The activities were therefore rather effective in teaching the rule for the volume of the truncated square pyramid, and the rule for the sum of consecutive positive Numbers. This type of activities should be used.

T29:We may solve similarity questions with the rules given in school, but I saw that in ancient China they were solved with the help of areas and by forming various figures. Thanks to the HoM, students may learn different solution methods. The HoM should therefore be utilized.

T30:Problem solution is important in mathematics, but students should also know why mathematics is important and why it should be used. For instance, interactivity about the birth of statistics, the students can learn why statistics is an important science. The HoM should therefore be incorporated into classes.

T36:In the activity about the sum of consecutive positive whole and square numbers, students can become aware of the relationship between geometry and mathematics. In other words, they may understand the relationship between different learning fields. This is why the HoM should be used in classes.

T17:In the activity about this sum of consecutive positive whole numbers and square whole numbers, they needed to use their previous knowledge in order to discover the rules. Four example, they needed to use the rule about the volume of a prism when finding the sum of square numbers.

\subsection{The Contributions of the Activities to the Prevention of Student-Related Obstacles}

Under this main category, there were two sub categories ("the students can evaluate the activities", "they are not unpleasant or boring"). Figure 5 shows the sub themes and codes which are created by analysing teacher candidates' written opinions. Afterwards, these sub themes and codes are provided with quotes taken from the interviews with 10 teacher candidates.

The teacher candidates stated that the activities they engaged in were relevant to course objectives $(\mathrm{f}=39)$ and that they did not require detailed knowledge about cultures $(\mathrm{f}=31)$. These views showed that students can evaluate the exercises.

T28:Among the HoM activities, we didn't focus on work in different cultures on a single topic at different times. Therefore, students don't need in-depth knowledge about cultures.

T21:Students don't need deep knowledge on cultures to be able to evaluate the exercises because the activities don't focus on how mathematical concepts evolve over time.

T13:As the activities are conducive to teaching the mathematical topics from today's textbooks, I don't think that the students would face the problem of not being able to evaluate the exercises. 


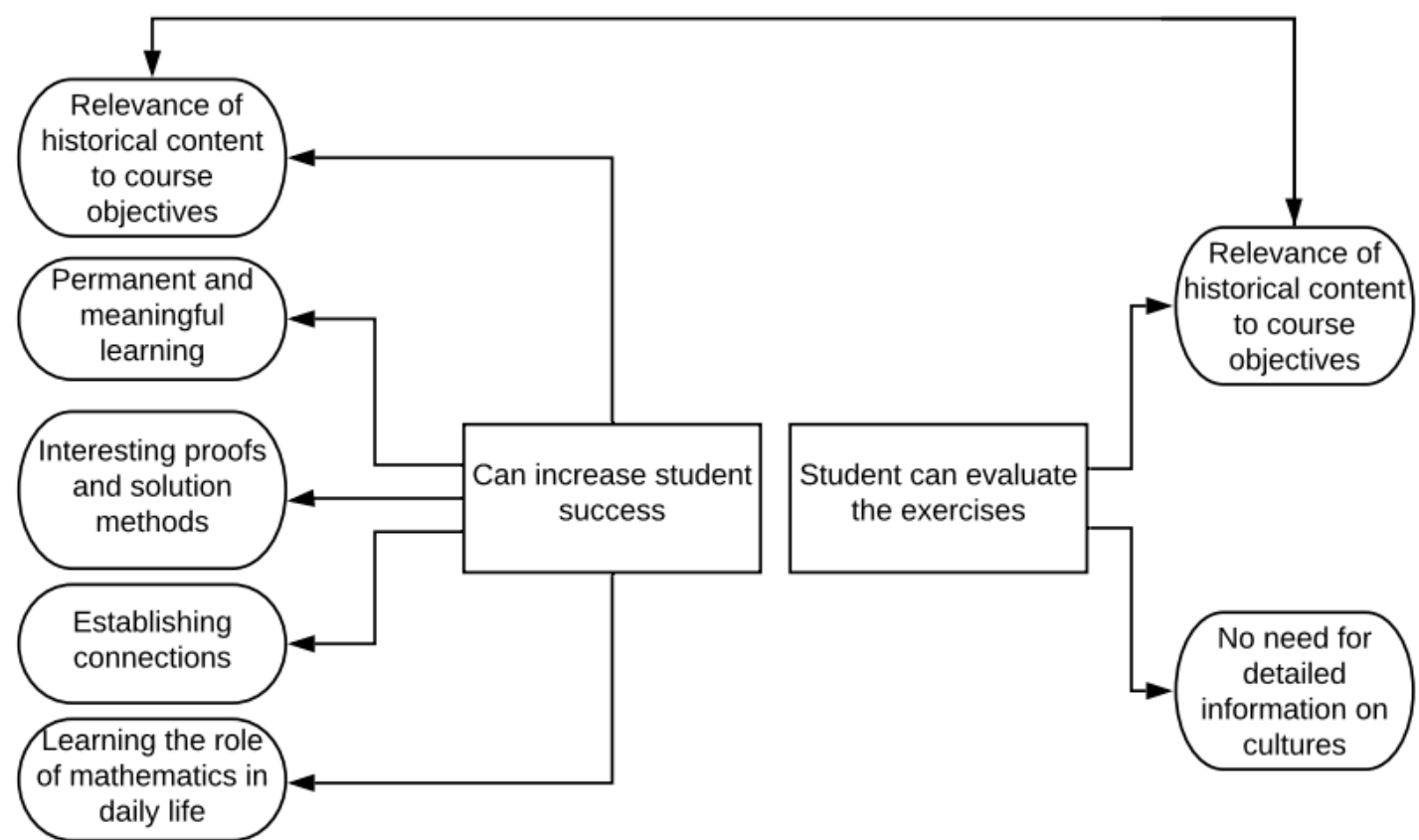

Figure 5. Subcategories and codes of the category "the contributions of the use of the HoM as a tool to the prevention of student-related obstacles"

Teacher candidates emphasized that the activities would not be viewed as unpleasant or boring by the students; on the contrary, they would like them. The reasons for this are in the five codes obtained in the data analyses. Teacher candidates also mentioned that the activities were relevant to the objectives of the mathematics textbooks $(\mathrm{f}=37)$, ensured permanent and meaningful learning $(\mathrm{f}=35)$, involved interesting proof and solution methods $(\mathrm{f}=28)$, and showed the students the everyday role of mathematics $(\mathrm{f}=20)$. They also added that some activities enabled students to connect them to algebra or geometry, thus ensuring that students who are not good at algebra but like geometry enjoy this type of activities $(\mathfrak{f}=12)$.

T2:There was no content in the activities that wasn't relevant to current mathematics. Therefore, the use of this type of historical content will not be boring for the students.

T4:Thanks to the activities, students learn what mathematical rules mean and they discover them. So they can learn the topics permanently. As the activities facilitate student learning, they won't be perceived as unpleasant or boring.

T10:In the similarity activity, we solved a problem with a good solution method. I expect the students to like this method.

T22:I think the use of wooden pieces and unit cubes made the activities interesting. Old civilizations used interesting proofs.

T39:There may be students who don't like algebra, but who like geometry. In some activities, we worked on algebra topics by making use of geometry. Therefore, those who like geometry will also like this type of activities.

T11:In the activity about ancient Egyptian measurement tools, students learned the importance of using standard measurement units. This will help them grasp the importance of the HoM.

T25:In the birth of statistics activity, students will understand the role and significance of statistics in daily life. Therefore with this type of activities, students will stop seeing the HoM unpleasant and boring.

\subsection{The Contributions of the Use of the HoM as a Tool to the Prevention of Stylistic Obstacles}

Under this main category, there were four sub categories ("there may be questions in the exam", "they are not confusing", "they may improve student success", "original historical texts are effective historical methods that can be used"). Figure 6 shows the sub themes and codes which are 
created by analysing teacher candidates' written opinions. Afterwards, these sub themes and codes are provided with quotes taken from the interviews with 10 teacher candidates.

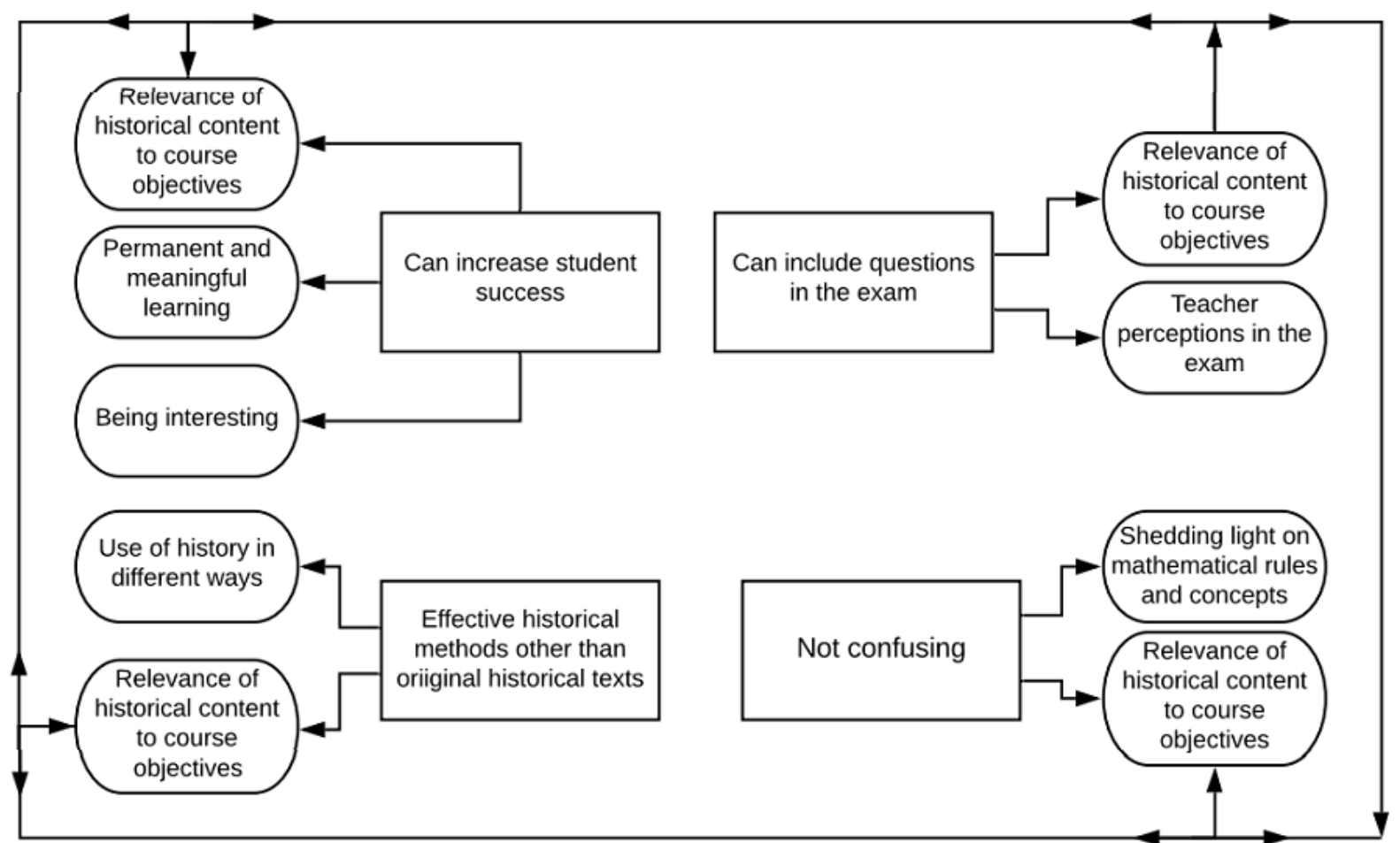

Figure 6. Subcategories and codes of the category "the contributions of the use of the HoM as a tool to the prevention of student-related obstacles"

Teacher candidates stated that the activities are related to the course objectives $(f=38)$ and can therefore be tested in exams. By noting that the real reason why exams do not have such questions is teachers' perceptions of historical content $(\mathrm{f}=31)$, they emphasized that the activities may teach teachers that historical content is not limited to life stories, historical representations unrelated to our day, or problem solutions given in old language.

T12:If the historical content is not relevant to our day's mathematics, it is normal that exams will not have questions on these. But the activities we engaged in were not like that.

T34:If we show the old notations of ancient number systems in the classroom, of course we cannot test this in the exams, but we can definitely ask exam questions about activities such as the volume of the truncated square pyramid, or Tabit Ibn Qurra's proof of the Pythagorean Theorem.

T3:If teachers limit history to life stories, published works, birth and death years, of course they will not include these in their exams. However, the activities showed us that history is not limited to these. It can be used to teach today's current concepts, too. Teachers can learn these via the activities and stop even remembering that obstacles such as this exist.

Teacher candidates were of the opinion that the activities were relevant to current mathematics $(\mathrm{f}=38)$ and shed light on mathematical rules and concepts $(\mathrm{f}=36)$. Therefore, the teacher candidates agreed that the activities would not lead to confusion on the students' part. At the same time, they stressed that as the activities are related to current mathematics $(f=37)$, are interesting $(f=34)$ and bring permanent-meaningful learning $(\mathrm{f}=37)$, they may improve student success.

T11:I disagree. They are not confusing. On the contrary, if the HoM is used with this type of activities, students will learn where rules and formula come from.

T30:There was an activity about the birth of statistics. In this activity, the students could grasp the role and importance of statistics for the society. Far from being confusing, this kind of an activity would inform and enlighten the students. 
T20:If we brought to the classroom historical books with outdated language or asked secondary school students to read original texts, they would probably be confused. But in these activities, we used texts related to today's mathematics. If we use history in this way, our students won't be confused.

T3:The activities we completed were related to today's mathematical topics. They aimed to help the students discover mathematical rules. Students don't easily forget discovered information, so I think the activities affected their success favorably.

T8:Thanks to these activities, students can learn where the rules come from and what meaning lies underneath. This allows for permanent learning. In addition, the materials are relevant to current topics. Therefore, I think they might improve student success.

T21:All of these activities would attract students' interest. They would therefore improve student success as well.

T15:The use of concrete learning objects and different solution methods would draw students' interest by showing them new sides of mathematics. And this would improve their success.

T2:If the teacher focuses on old notations and solutions in old language, such content would not improve student success; in fact, students may find it boring. As we did in these activities, solving similarity questions via the ancient Chinese method of areas may increase student success.

Referring to the various concrete learning objects used in the activities $(f=38)$, teacher candidates stated that the use of the HoM is not only limited to original historical texts. They also noted that the historical content should also match the topics in the current mathematics textbook $(\mathrm{f}=36)$.

T32:The HoM is not limited to the use of original texts. For instance, through the activities the students learned current mathematical rules by using proofs used by mathematicians and various cultures.

T4:It may not be useful to use original texts for secondary school students but the activities showed that the HoM can be used in the classroom in various ways.

T5:Using original texts in classes may lead to both time loss and student alienation from the classroom when the texts are not relevant to today's mathematics. Our activities, on the other hand, had contents relevant to current mathematics.

T28:Original texts can be used with university students. For secondary school students, historical content adapted to today's mathematics would be useful. We saw this in the activities.

\subsection{The Contributions of the Use of the HoM as a Tool to the Prevention of Instructional Preparation Obstacles}

Under this main category, there were two sub categories ("No lack of materials" and "being able to evaluate the accuracy of practices"). Figure 7 shows the sub themes and codes which are created by analysing teacher candidates' written opinions. Afterwards, these sub themes and codes are provided with quotes taken from the interviews with 10 teacher candidates.
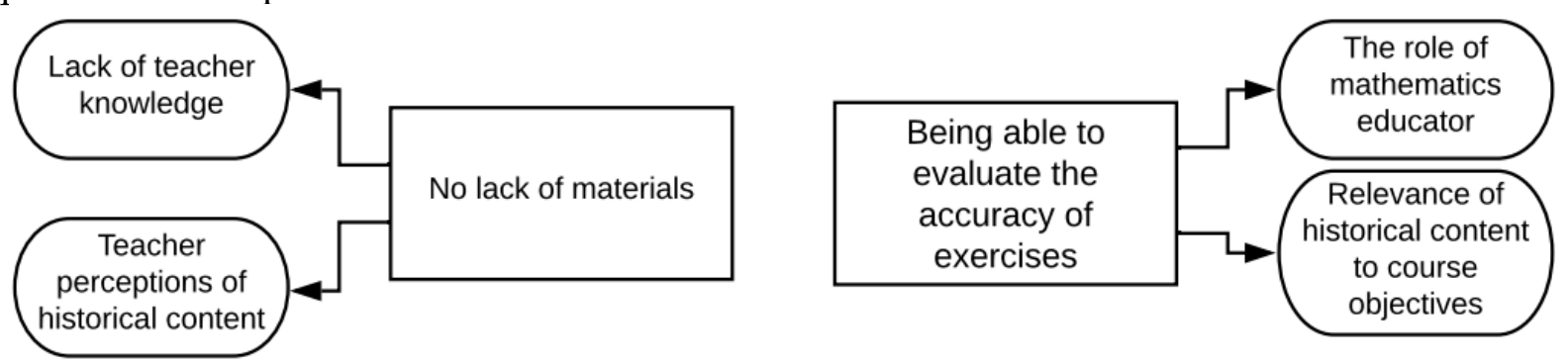

Figure 7. Subcategories and codes of the category "the contributions of the use of the HoM as a tool to the prevention of instructional preparation obstacles"

Teacher candidates referred to the materials used in the activities, and stated that there was no such obstacle. They noted that the reasons for such an obstacle might be the lack of teachers' knowledge and experience $(\mathrm{f}=32)$ and their perceptions of historical content $(\mathrm{f}=36)$. 
T11:I don't think this obstacle really exists. The activities and materials show this. I think thie obstacle only emerges because teachers do not know how to use the HoM.

T22:The activities taught me that I can prepare may materials related to the HoM. I think this is related to teachers' lack of knowledge and experience.

T20:If teachers think the HoM is only to be used via life stories and the like, such an obstacle naturally emerges. But the activities reveal that the HoM can be used to teach a topic.

T7:The word history may conjure history as we know it in the teacher's mind. This may be the reason why they say materials are hard to find, But I think the HoM can be used in many ways, for example to find the volume rule for the volume of the truncated square pyramid, or the one for consecutive positive whole numbers.

According to the teacher candidates, mathematics educators should use the HoM to teach mathematical topics and draw students' attention $(\mathrm{f}=27)$. They stated that the activities were conducive to this, and therefore teachers could evaluate the accuracy of the activities. In addition, teacher candidates agreed that the activities were related to and aligned with current mathematics $(\mathrm{f}=37)$ and that the teachers can evaluate their accuracy.

T16:We teachers try to teach the students the best we can. We are therefore not mathematics historians, but mathematics educators. Our aim is to use history to teach mathematics topics. These activities are suitable for our role as mathematics educators. Therefore, teachers can easily evaluate the accuracy of what they do.

T9:No deep cultural analysis is needed to prepare the activities as our aim as teachers is to use historical content, and to use it to teach the textbook topics.

T8:The activities showed that you do not need to be a professional mathematics historian to prepare and implement such activities as we can adapt the proof methods of ancient civilizations to use in today's classrooms.

T15:We can bring the measurement units of ancient Egypt to the classroom and ask the students to make measurements with them. In this way, we can help students understand the importance of using standard measurement units. One does not need to be a professional mathematics historian to do this.

Other than the original opinions obtained from the students, interviews were conducted with 10 teacher candidates to ask them "Would this type of activities cause the ........ obstacle to the use of the HoM (for example, lack of time, lack of materials, etc.)? Why? The findings from interview data analyses are presented in Table 2.

Table 2.

Findings from the data analysis of the interviews

\begin{tabular}{lccc}
\hline Obstacle & Causes & Does not cause & Partially causes \\
\hline Lack of time & 0 & 10 & 0 \\
\hline It is unnecessary to use history & 0 & 10 & 0 \\
\hline It is not irrelevant to mathematics & 0 & 10 & 0 \\
\hline Students cannot evaluate the exercises & 0 & 10 & 0 \\
\hline It is unpleasant and boring & 0 & 10 & 1 \\
\hline It is confusing & 0 & 9 & 0 \\
\hline It cannot be tested in exams & 0 & 10 & 0 \\
\hline It does not improve student success & 0 & 10 & 0 \\
\hline $\begin{array}{l}\text { There is not benefit to using original } \\
\text { historical texts }\end{array}$ & 0 & 10 & 0 \\
\hline Materials are hard to find & 0 & 10 & 0 \\
\hline $\begin{array}{l}\text { Teachers evaluate the accuracy of the } \\
\text { exercises }\end{array}$ & 0 & & 0 \\
\hline
\end{tabular}


Findings from the interview data analysis paralleled those from the written opinion forms. Nine teacher candidates expressed positive views on the use of mathematics history. They emphasized that the activities are related to the course objectives, support permanent and meaningful learning and the historical content is used in a planned way in the activities and state that such use of the HoM eliminates obstacles. Teacher candidates' opinions revealed that they found the activities instructive and fun. They thought that concrete models made classes more enjoyable and figuring out the rules themselves was instructive. Only one teacher candidate (T9) mentioned that the activities may bring partial confusion. Below is a section from the interview with T9:

A: Do you think the use of the HoM in classes may confuse students?

T9: It is possible, though partially.

A: How? Can you exemplify?

T9: Some students, particularly those with poor mathematical skills and poor infrastructure in mathematics, may find certain activities confusing.

A: What activities, for instance?

T9: For instance, when finding the rule for the sum of square numbers, the figure that we formed had extra cubes on top. Some students may be confused by this. We divided them into two equal parts and obtained a prism.

A: And wouldn't this invite students to think, use their judgment?

T9: Yes, students push their mind to solve the problem. It's useful in this respect.

Teacher candidate T9 argued that certain activities may be confusing for students with weak mathematics skills who do not have a solid mathematics background. However, in the interview, T9 did not mention the risk of confusion regarding historical content. On the contrary, teacher candidates stated that the activities would be beneficial for students as they would challenge their minds and encourage them to make judgments.

\section{Discussion and Conclusion}

In this study, teacher candidates were asked to evaluate activities designed with the use of the history of mathematics (HoM) as a tool in terms of the obstacles to the use of the HoM. The findings showed that the activities used in this study could be used in mathematics classes and similar activities may stop the emergence of philosophical, student-related, stylistic and instructional preparation obstacles. "Time issues", "the irrelevance of history to mathematics" and "the low necessity of using history" are included in philosophical obstacles. Teacher perceptions that the mathematics class involves unchanging rules and formula and solves routine problems leads to the conclusion that the HoM is not relevant to the mathematics class (Haverhals and Roscoe, 2010). Indeed, Horton and Panasuk (2011) reported that teachers with absolutist views about the nature of mathematics use the HoM less than teachers who hold quasi-experimental beliefs. Therefore, teachers' tendency to use the HoM in their classes is closely related to their beliefs about the nature of mathematics. In addition, time problems due to teacher efforts to keep up with loaded school curricula emerge as another obstacle to the use of the HoM. Therefore, the activities avoided using hard-to-understand historical texts not related with today's mathematics and solutions written in outdated language. Thanks to the activities, teacher candidates discovered mathematical rules and concepts from current textbooks by using interesting and different solutions and proof methods. Teacher candidates used their geometry knowledge when discovering mathematical rules. They also became aware of the role and significance of mathematics in the society. Therefore, teacher candidates stated that philosophical obstacles would not emerge if this type of activities were used in classes. Lit et al., (2001) also argued that the historical content must be related to today's mathematics. Dickey (2001) voiced concerns that some students in his study may stay behind in the mathematics curriculum due to the use of historical content in their classes, and that the knowledge they gained during the study may not be useful. Student-related obstacles to the use of the HoM include student dislike of the HoM, classes being boring and students not being able to evaluate the exercises. Teacher candidates stated that the 
content of activities was related to today's mathematics. Teacher candidates discovered the rules in current mathematics textbooks by using proof methods from different civilizations. They made use of concrete learning objects in the discovery process. For instance, in activities 8 and 10, they discovered the volume rule for truncated square pyramid and truncated rectangular pyramid by using the cut and disintegrate method. Teacher candidates found proof and solution methods used by different civilizations interesting and had the opportunity for permanent learning. In activities 9, 11 and 12, when teacher candidates were discovering the rules in the algebra learning area, they made use of the areas and volumes of geometric figures. To illustrate, in activity 9 , they found the long form of $(a+b)^{3}$ by using a cubic model with side length $\mathrm{a}+\mathrm{b}$ (Appendix 2; Activity 9). In activity 11, they found the rule for the sum of square numbers by using the volume of a prism (Appendix 3, as students studied), and in activity 12, they found the rule for the sum of consecutive positive whole numbers by using the areas of a rectangle and square. In this way, they could see the link between mathematics and geometry. Teacher candidates found this use of the HoM interesting. They emphasized that this type of activities would indeed attract their attention and that the students would willingly work on such activities. Therefore Siu's (2007) claim that "students do not like the HoM" does not parallel the findings from the study. Similar to the finding of the present study, the students in Haverhals and Roscoe's (2010) study stated that classes based on the historical approach were interesting and they participated in the classes willingly. Dittrich (1973); Lawrence (2006), Lim (2011); McBride and Rollins (1977), Ponza (1998) also found similar results in their studies.

The stylistic obstacles to the use of the HoM included "not being tested in exams", "not contributing to student success", "being confusing" and "lack of usefulness in historical original texts". Teacher candidates claimed that the activities could be used in contemporary mathematics classes, and they discovered the mathematical rules included in today's textbooks by using concrete learning objects. They came across with unfamiliar but interesting solutions and proof methods. For instance, they solved similarity questions by using the disintegrate and combine method (Appendix 3, student work). Such activities helped teacher candidates develop ideas that the use of the HoM would not cause stylistic obstacles. Lit et al. (2001) concluded in their study that the success of experimental students decreased as compared to control students. The researchers explained this with the answers given to questions such as "what is taught as historical content" and "how the learning is evaluated". This view shows that historical content should be used in a way to serve the teaching of current mathematical concepts, as in the present study. Haverhals and Roscoe (2010), found in their study that the use of the HoM increased students' willingness to learn and their interest in the topic. They also claimed that the HoM would help richer and more meaningful learning, and improve student grades. Even though Siu (2007) claims that no study exists showing that the use of the HoM contributes to student learning, studies by Albayrak (2011), Awosanya (2001), Bütüner (2016), Glaubitz (2007), İdikut (2007), Leng (2006), Lim (2011), Nataraj and Thomas (2009), Lim and Chapman (2015) all reveal that the use of the HoM makes positive effects on students' cognitive development.

Obstacles to instructional readiness include "lack of materials" and "teachers' inability to evaluate the accuracy of the exercises". Throughout the study, the teacher candidates were exposed to many materials. They therefore stated that there were no problems with availability of the HoM materials. They argued that this obstacle stems from teachers with lack of knowledge and experience in the HoM, as such teachers only use history in their classes in the form of life stories, birth and death dates of mathematicians and their works. Indeed, Panasuk and Horton (2012), reported that teachers trained in the use of the HoM had more knowledge and experience and therefore used the HoM more often in their classes. Gazit (2013), in a study aiming to determine mathematics teachers' and teacher candidates' HoM knowledge levels, concluded that teachers were not knowledgeable about when the probability principle was posited, who first calculated the pi number, where the word algorithm comes from, and who invented natural numbers. Teacher candidates stated that the activities were relevant to contemporary mathematics and that 
the accuracy of such exercises can be evaluated by teachers. In sum, the views of teacher candidates at the end of the study revealed that no obstacles would emerge to the use of the HoM only if those activities are well-created. In the future, longer-term studies may be conducted with mathematics teachers and secondary school students with the activities used in this study. In this way, stronger evidence may be obtained about the effectiveness of using these such activities in the instructional process.

\section{References}

Albayrak, Ö. (2008). Effects of history of mathematics integrated instruction on mathematics self-efficacy and achievement. Unpublished master thesis. Boğaziçi University, İstanbul.

Awosanya, A. (2001). Using history in the teaching mathematics. Unpublished doctoral dissertation, Florida State University, America.

Bengtsson, M. (2016). How to plan and perform a qualitative study using content analysis. NursingPlus Open, 2, 8-14.

Baki, A., \& Gürsoy, K. (2018). Does using history of mathematics make sense? The views of teacher candidates. Journal of Pedagogical Research, 2(2), 78-90.

Bütüner, S. Ö. (2016). The use of concrete learning objects taken from the history of mathematics in mathematics education. International Journal of Mathematical Education in Science and Technology, 47(8), 1156-1178. https://doi.org/10.1080/0020739X.2016.1184336.

Clark, K. M. (2012). History of mathematics: illuminating understanding of school mathematics concepts for prospective mathematics teacher. Educational Studies in Mathematics, 81(1), 67-84. https://doi.org/10.1007/s10649-011-9361-y.

Clark, K. M., Kjeldsen, T. H., Schorcht, S., \& Tzanakiz, C. (2018). Introduction: integrating history and epistemology of mathematics in mathematics education. In Clark, K. M., Kjeldsen, T. H., Schorcht, S., \& Tzanakis, C. (Eds.), Mathematics, education and history: towards a harmonious partnership (pp.1-26), Switzarland: Springer International Publishing.

Dauben, J. W. (2007). Chinese Mathematics. In Katz, V. (Ed.) The Mathematics of Egypt, Mesopotamia, China, India, and Islam (pp.187-380), Princeton University Press, New Jersey.

Dickey, G. (2001). A historical approach to teaching the british columbia mathematics eight course. Unpublished master's thesis, Simon Fraser University.

Dilke, O. A. W. (1993). Mathematics and measurement. British Museum Publications Ltd: London.

Dittrich, A. B. (1973). An experiment in teaching the history of mathematics. Mathematics Teacher, 66(1), 35-37.

Elo, S., \& Kyngäs, H. (2008). The qualitative content analysis process. Journal of Advanced Nursing, 62, 107-115. doi: 10.1111/j.1365-2648.2007.04569.x.

Erlingsson, C., \& Brysiewicz, P. (2017). A hands-on guide to doing content analysis. African Journal of Emergency Medicine, 7(3), 93-99. https://doi.org/10.1016/j.afjem.2017.08.001.

Ernest, P. (1989). The impact of beliefs on the teaching of mathematics. In P. Ernest (Ed.), Mathematics teaching: the state of the art (pp. 249-254). New York, Falmer

Ernest, P. (1998). The history of mathematics in the classroom. Mathematics in School, 27(4). 25-31. https://www.jstor.org/stable/30211871.

Fauvel, J. (1991). Using history in mathematics education. For the Learning of Mathematics, 11(2), 3-6. https://eric.ed.gov/?id=EJ445129.

Fraser, J. B., \& Koop, J. A. (1978). Teachers' opinions about some teaching material involving history of mathematics. International Journal of Mathematical Education in Science and Technology, 9(2), 147-151. https://doi.org/10.1080/0020739780090203.

Fried, N. M. (2001). Can mathematics education and history of mathematics coexist?. Scince and Education, 10, 391-408. https://doi.org/10.1023/A:1011205014608.

Furinghetti, F., \& Somaglia, A. M. (1998). History of mathematics in school across disciplines. Mathematics in School, 27(4), 48-51. https://www.jstor.org/stable/30211877.

Furinghetti, F. (2007) Teacher education through the history of mathematics. Educational Studies in Mathematics, 66(2), 131-143. https://doi.org/10.1007/s10649-006-9070-0.

Gazit, A. (2013). What do mathematics teachers and teacher trainees know about the history of mathematics?. International Journal of Mathematical Education in Science and Technology, 44(4), 501-512. https://doi.org/10.1080/0020739X.2012.742151. 
Glaubitz, M. R. (2007). The use of original sources in the classroom. Proceedings of the 5th European Summer University, 19-24 Temmuz, Prague.

Gulikers, I., \& Blom, K. (2001). A historical angle, a survey of recent literature on the use and value of history in geometrical education. Educational Studies in Mathematics, 47, 223-258. https://doi.org/10.1023/A:1014539212782.

Haverhals, N., \& Roscoe, M. (2010). The history of mathematics as a pedagogical tool: teaching the integral of the secant via Mercator's projection. The Montana Mathematics Enthusiast, 7(2-3), 339-360. https://scholarworks.umt.edu/tme/vol7/iss2/12.

Ho, W. K. (2008). Using history of mathematics in the teaching and learning of mathematics in Singapore. In Proceedings of 1st RICE (pp. 1-38), Singapore: Raffles Junior.

Horton, L. B. (2011). High school teachers' perception of the inclusion of history of mathematics in the classroom. Unpublished doctoral dissertation, University of Massachusetts lowel.

Huntley, M. A., \& Flores, A. (2010). A history of mathematics course to develop prospective secondary mathematics teachers' knowledge for teaching. Primus, 20(7), 603-616. https://doi.org/10.1080/10511970902800494.

Huntley, M. A., \& Flores, A. (2011). Student made games to learn the history of Mathematics. Primus, 21(6), 567-576. doi: 10.1080/10511970903521651.

Hsieh, H. F., \& Shannon, S. (2005). Three approaches to qualitative content analysis. Qualitative Health Research, 15, 1277-1288. doi: 10.1177/1049732305276687.

İdikut, N. (2007). The effect of benefiting from history in education of mathematics on the student's attitudes towards mathematics and their success on it, Unpublished master dissertation, Van: Yüzüncü Yıl University.

Jankvist, T. U. (2009a). Using history as a goal in mathematics education. Unpublished doctoral dissertation, Roskilde University.

Jankvist, T. U. (2009b). A categorization of the whys and hows of using history in mathematics education. Educational Studies in Mathematics Education, 71(3), 235-261. https://doi.org/10.1007/s10649-008-9174-9.

Kaye, E. (2008). The aims of and responses to a history of mathematics video conferencing project for schools, In Proceedings of the British for Research into learning mathematics, 28(3), 66-71.

Lawrence, S. (2006). Maths is good fot you: web-based history of mathematics resources for young mathematicians and their teachers. Journal of the British Society for the History of Mathematics, 21, 90-96. https://doi.org/10.1080/17498430600803375.

Leng, N. W. (2006). Effects of an ancient chinese mathematics enrichment programme on secondary school students' achievement in mathematics. International Journal of Science and Mathematics Education, 4, 485511. https://doi.org/10.1007/s10763-005-9017-4.

Lim, S. Y. (2011). Effects of using history of mathematics on junior college students' attitudes and achievement, In Proceedings of AAMT-MERGA Conference 2011 Mathematics: Traditions and New Practices, 455-463.

Lim, S., Chapman, E. (2015). Effects of using history as a tool to teach mathematics on students' attitudes, anxiety, motivation and achievement in grade 11 classrooms. Educational Studies in Mathematics, 90, 189212. https://doi.org/10.1007/s10649-015-9620-4

Liu, P. (2003). Do teachers' need to incorporate the history of mathematics in their teaching?. Mathematics Teacher, 96(6), 416-421.

Lit, C. K., Siu, M. K., \& Wong, N. Y. (2001). The use of history in the teaching of mathematics: theory, practice, and evaluation of effectiveness. Educational Journal, 29(1), 17-31.

Lumpkin, B. (1997a). Algebra activites from many cultures. USA: J. Weston Walch Publisher.

Lumpkin, B. (1997b). Geometry activites from many cultures. USA: J Weston Walch Publisher.

Marshall, G. L., \& Rich, B. S. (2000). The role of history in a mathematics class. Mathematics Teacher, 93(8), 704-706. https://www.jstor.org/stable/27971554.

McBride, C. C., \& Rollins, H. J. (1977). The effects of history of mathematics on attitudes toward mathematics of college algebra students. Journal for Research in Mathematics Education, 8(1), 57-61. https://www.jstor.org/stable/748568.

Nataraj, M. S., \& Thomas, M. O. J. (2009). Developing understanding of number system structure from the history of mathematics. Mathematics Education Research Journal, 21(2), 96-115. https://doi.org/10.1007/BF03217547.

NCTM (1989). Curriculum and evaluation standarts for school mathematics. Reston, VA: Author.

NCTM (2006). Historical topics for the mathematics classroom. Reston, VA: Author. 
Panasuk, R. M., \& Horton, L. B. (2012). Integrating history of mathematics into curriculum: what are the chances and constraints?. International Electronic Journal of Mathematics Education, 7(1), 3-20. https://www.iejme.com/article/integrating-history-of-mathematics-into-curriculum-what-are-thechances-and-constraints.

Ponza, M. V. (1998). A role for the history of mathematics in the teaching and learning of mathematics: An Argentinean experience. Mathematics in School, 27(4), 10-13.

Reimer, W., \& Reimer, L. (2012). Historical connections in mathematics Volume I: Resources for using history of Mathematics in the classroom. California: AIMS Educational Foundation.

Reimer, W., \& Reimer, L. (2005). Historical connections in mathematics Volume II: Resources for using history of Mathematics in the classroom. California: AIMS Educational Foundation.

Reimer, W., \& Reimer, L. (2010). Historical connections in mathematics Volume III: Resources for using history of Mathematics in the classroom. California: AIMS Educational Foundation.

Sip, J. (1990). But everybody accepts this explanation: operations on signed numbers. In Fauval, J. (Ed.) History in the mathematics classroom: the IREM papers (pp.73-84). The Mathematical Association.

Siu, M.-K. (2007). No, I don't use history of mathematics in my class. Why? In F. Furinghetti, S. Kaijser, \& C. Tzanakis (Eds.), Proceedings HPM2004 \& ESU4 (revised edition, pp. 268-277). Uppsala: Uppsala Universitet.

Swetz, F. J. (1994). Learning activities from the history of mathematics. Portland: Walch Publishing.

Swetz, J. W. (1997). Using problems from the history of mathematics in classroom instruction, In Swetz, F., Fauval, J., Bekken, O., Johansson, B. and Katz, V. (Eds.) Learn from the masters (pp.25-38). The Mathematical Association of America.

Tözluyurt, E. (2008). The perceptions of senior high students regarding the lessons, in which activities chosen from history of mathematics are used on the subject of numbers learning area. Unpublished master dissertation, Ankara: Gazi University.

Tzanakis, C., \& Arcavi, A. (2000). Integrating history of mathematics in the classroom: an analytic survey. In Favuel, J., \& Van Manen, J. (Eds.), History in mathematics education (pp. 201-240), Netherlands: Kluwer Academic Publishers.

Vaismoradi, M., Bondas, T., \& Turunen, H. (2013). Content analysis and thematic analysis: Implications for conducting a qualitative descriptive study. Journal of Nursing \& Health Sciences, 15, 398-405. doi: $10.1111 /$ nhs. 12048 .

Wang, Y. (2009). Hands on mathematics: two cases from ancient Chinese mathematics. Science \& Education, 18, 631-640. https://doi.org/10.1007/s11191-007-9078-6.

Wang, X., Qi, C., \& Wang, K. (2017). A Categorization model for educational values of the history of mathematics. Science \& Education, 26, 1029-1052. https://doi.org/10.1007/s11191-017-9937-8.

Werner H., \& Gholam A. Z. (1998) THE Pythagorean theorem and related topics a resource for geometry teachers. Problems, Resources, and Issues in Mathematics Undergraduate Studies, 8(4), 365-383. https://doi.org/10.1080/10511979808965910. 
Appendix 1.

Activities Designed to Use HoM as a Tool

\begin{tabular}{|c|c|c|c|c|}
\hline No & Name of Activity & Level & Objective & Time \\
\hline 1 & $\begin{array}{l}\text { Argand and the sign law in } \\
\text { multiplication (Sip, 1990). }\end{array}$ & $\begin{array}{l}\text { Secondary } \\
\text { school }\end{array}$ & $\begin{array}{l}\text { Carries out } \\
\text { multiplication with } \\
\text { whole numbers }\end{array}$ & $\begin{array}{l}28.09 .2018 \\
\text { Week } 1\end{array}$ \\
\hline 2 & $\begin{array}{l}\text { Thabit ibn Qurra Pythagorean } \\
\text { Theorem (Werner and Gholam, } \\
\text { 1998). }\end{array}$ & $\begin{array}{l}\text { Secondary } \\
\text { school }\end{array}$ & $\begin{array}{l}\text { Constructs the } \\
\text { Pythagorean Theorem }\end{array}$ & $\begin{array}{l}28.09 .2018 \\
\text { Week } 1\end{array}$ \\
\hline 3 & $\begin{array}{l}\text { The birth and significance of } \\
\text { statistics (Lumpkin, 1997a) }\end{array}$ & $\begin{array}{l}\text { Secondary } \\
\text { school }\end{array}$ & $\begin{array}{l}\text { Understands the role of } \\
\text { statistics and its } \\
\text { significance for the } \\
\text { society }\end{array}$ & $\begin{array}{l}05.10 .2018 \\
\text { Week } 2\end{array}$ \\
\hline 4 & $\begin{array}{l}\text { The importance of the use of } \\
\text { measurement and standard } \\
\text { measurement tools in ancient } \\
\text { Egypt (Dilke, 1993; Lumpkin, } \\
\text { 1997a) }\end{array}$ & $\begin{array}{l}\text { Secondary } \\
\text { school }\end{array}$ & $\begin{array}{l}\text { Understands the } \\
\text { importance of using } \\
\text { standard measurement } \\
\text { tools }\end{array}$ & $\begin{array}{l}05.10 .2018 \\
\text { Week } 2\end{array}$ \\
\hline 5 & $\begin{array}{l}\text { The solution of similarity } \\
\text { problems with the cut and divide } \\
\text { method in ancient China (Dauben, } \\
\text { 2007; Wang, 2009) }\end{array}$ & $\begin{array}{l}\text { Secondary } \\
\text { school }\end{array}$ & $\begin{array}{l}\text { Solves similarity } \\
\text { problems }\end{array}$ & $\begin{array}{l}\text { 12.10.2018 } \\
\text { Week } 3\end{array}$ \\
\hline 6 & $\begin{array}{l}\text { Finding the height of objects with } \\
\text { Thales' theorem (Reimer and } \\
\text { Reimer, 2005). }\end{array}$ & $\begin{array}{l}\text { Secondary } \\
\text { school }\end{array}$ & $\begin{array}{l}\text { Solves similarity } \\
\text { problems by using the } \\
\text { Thales theorem }\end{array}$ & $\begin{array}{l}\text { 12.10.2018 } \\
\text { Week } 3\end{array}$ \\
\hline 7 & $\begin{array}{l}\text { Eratosthenes and Earth's } \\
\text { circumference (Lumpkin, 1997b; } \\
\text { Reimer and Reimer, 2010). }\end{array}$ & $\begin{array}{l}\text { Secondary } \\
\text { school }\end{array}$ & $\begin{array}{l}\text { Calculates the } \\
\text { circumference of the } \\
\text { Earth by using ratio and } \\
\text { proportion }\end{array}$ & $\begin{array}{l}\text { 19.10.2018 } \\
\text { Week } 4\end{array}$ \\
\hline 8 & $\begin{array}{l}\text { The volume formula for truncated } \\
\text { rectangular pyramid (Swetz, 1994) }\end{array}$ & $\begin{array}{l}\text { High } \\
\text { School }\end{array}$ & $\begin{array}{l}\text { Constructs the volume } \\
\text { formula for truncated } \\
\text { rectangular pyramid }\end{array}$ & $\begin{array}{l}\text { 19.10.2018 } \\
\text { Week } 4\end{array}$ \\
\hline 9 & $\begin{array}{l}\text { The long form of }(a+b)^{3} \text { in } \\
\text { ancient China (Dauben, 2007; } \\
\text { Huntley and Flores, 2011) }\end{array}$ & $\begin{array}{l}\text { High } \\
\text { School }\end{array}$ & $\begin{array}{l}\text { Constructs the long } \\
\text { form of }(a+b)^{3}\end{array}$ & $\begin{array}{l}26.10 .2018 \\
\text { Week } 5\end{array}$ \\
\hline 10 & $\begin{array}{l}\text { The volume formula for truncated } \\
\text { square pyramid in ancient Egypt } \\
\text { (Swetz, 1994) }\end{array}$ & $\begin{array}{l}\text { High } \\
\text { School }\end{array}$ & $\begin{array}{l}\text { Constructs the volume } \\
\text { formula for square } \\
\text { rectangular pyramid }\end{array}$ & $\begin{array}{l}26.10 .2018 \\
\text { Week } 5\end{array}$ \\
\hline 11 & $\begin{array}{l}\text { The rule for the sum of square } \\
\text { numbers in ancient China } \\
\text { (Dauben, 2007; Wang, 2009) }\end{array}$ & $\begin{array}{l}\text { High } \\
\text { School }\end{array}$ & $\begin{array}{l}\text { Builds the rule for the } \\
\text { sum of square numbers. }\end{array}$ & $\begin{array}{l}02.11 .2018 \\
\text { Week } 6\end{array}$ \\
\hline 12 & $\begin{array}{l}\text { The sum of consecutive positive } \\
\text { whole numbers with Gauss and } \\
\text { Yang Hui (Wang, 2009; Reimer } \\
\text { and Reimer, 2012) }\end{array}$ & $\begin{array}{l}\text { High } \\
\text { School }\end{array}$ & $\begin{array}{l}\text { Builds the rules for the } \\
\text { sum of consecutive } \\
\text { positive whole numbers. }\end{array}$ & $\begin{array}{l}02.11 .2018 \\
\text { Week } 6\end{array}$ \\
\hline
\end{tabular}


Appendix 2. Activities 1,3,4,8 and 9 used in the study

\section{Activity 1}

Jean-Robert Argand (1768-1822) was an amateur mathematician from France. He published the Argand diagram known as complex numbers with geometric interpretations. Let us assume that the two numbers to be multiplied in the diagram are 1 and $i$.

1 and $i$ have positive direction. As one proceeds from 1 to i counter-clockwise the result will be positive. Therefore $1 x i=i$.

When 1 and -i are multiplied, 1 is in the positive direction and $-\mathrm{i}$ in negative direction. As one proceeds from 1 to $-\mathrm{i}$ clockwise the result will be negative. Therefore $1 x-i=-i$. We may consider French mathematician Argand's view for the multiplication of two whole numbers as well. For instance, in $3 x(-2)$ below, 3 and -2 are first shown on the vertical coordinate system. With 3 on the $x$ axis and -2 on the $\mathrm{y}$ axis, as the direction from 3 to -2 (from the $\mathrm{x}$ axis to $\mathrm{y}$ ) counter-clockwise, the result is negative.

The sum will be -6 .

Activity: Understands the Rule of Signs in multiplication Learning Area: Number-Operation

Group: 2 people

Duration: One class hour

\section{Instructions}

Model the operations below in the coordinate system by using Jean Robert Argand's direction idea and find the sums. $4 \times(-6), \quad(-3) \times(-5), \quad(-7) \times 8$
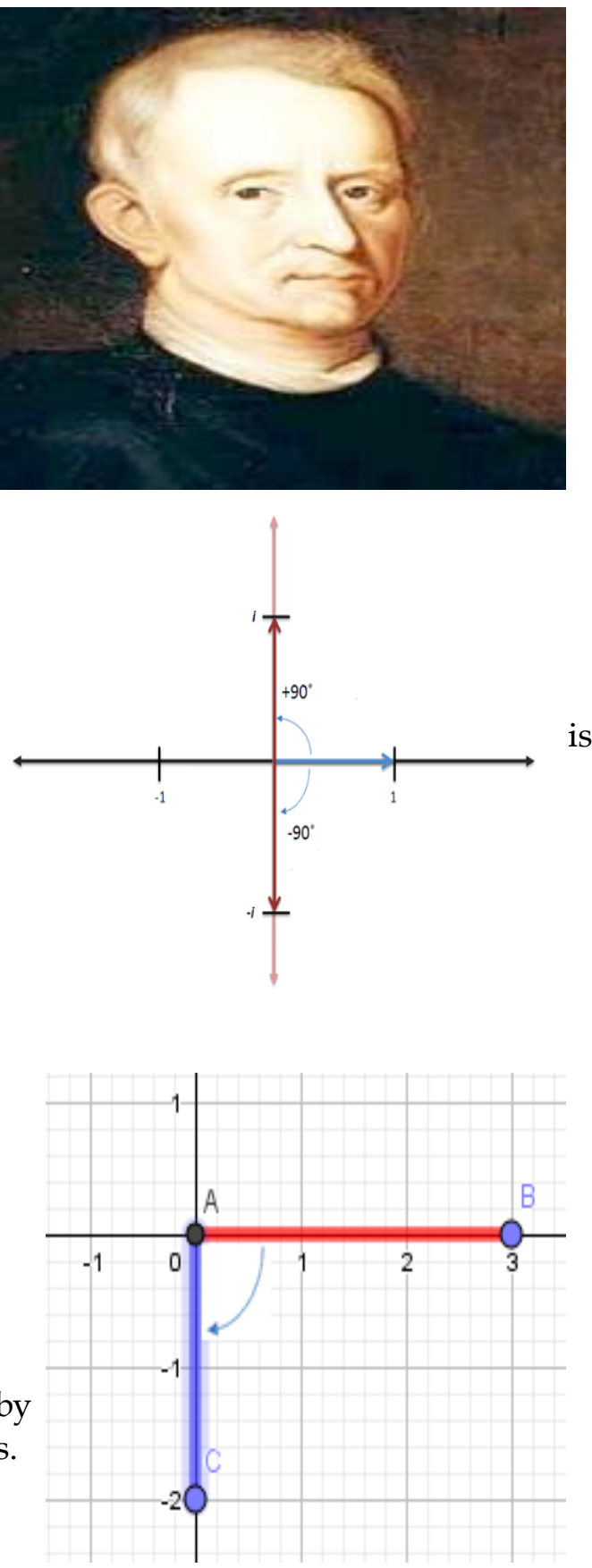


\section{Activity 3}

This activity aims to teach the role and importance of the science of statistics in the society by showing which civilization first undertook data collection and recording, and their reasons; who wrote the first statistics book and when; and what the contents were. In addition, historical resources were used to ask students to read tables in them and transmit these data to graphics.

Activity: Reading tables from historical resources, interpretation

Learning Area: Data and Probability

Grade Level-Duration: Grade 7 - 1 class hour

Group: 1 person

Duration: One class hour

\section{Instructions}

1.In the introduction to the topic, the information below is shared.

We can state that the earliest statistical data collection took place in ancient Egypt. The well-being of the people in ancient Egypt relied on the irrigation of their crops with just enough water from the River Nile. However, during years when the overflow from the great river was not enough, crops did not get enough water and famine followed. Similarly, when there was a flood (water above 17 cubits), it destroyed houses and water canals. Therefore, the Egyptian administration of the time stored crops in case the water overflow from the Nile was not enough. In ancient Egypt, the water levels were recorded for thousands of years. Annual water level was read and recorded with a measurement tool called the Nilometer (see picture) and the expected amount of crops was calculated. They defined their agricultural fields with the unit "arouras". 1 arouras equalled 10,000 cubit'2 ${ }^{2}$. If 1 cubit was approximately $52,3 \mathrm{~cm}, 1$ arouras would today be equal to approximately 2735,2 square meters.

The table below presents the overflow levels and irrigated area measurements. Answer the questions based on the table.

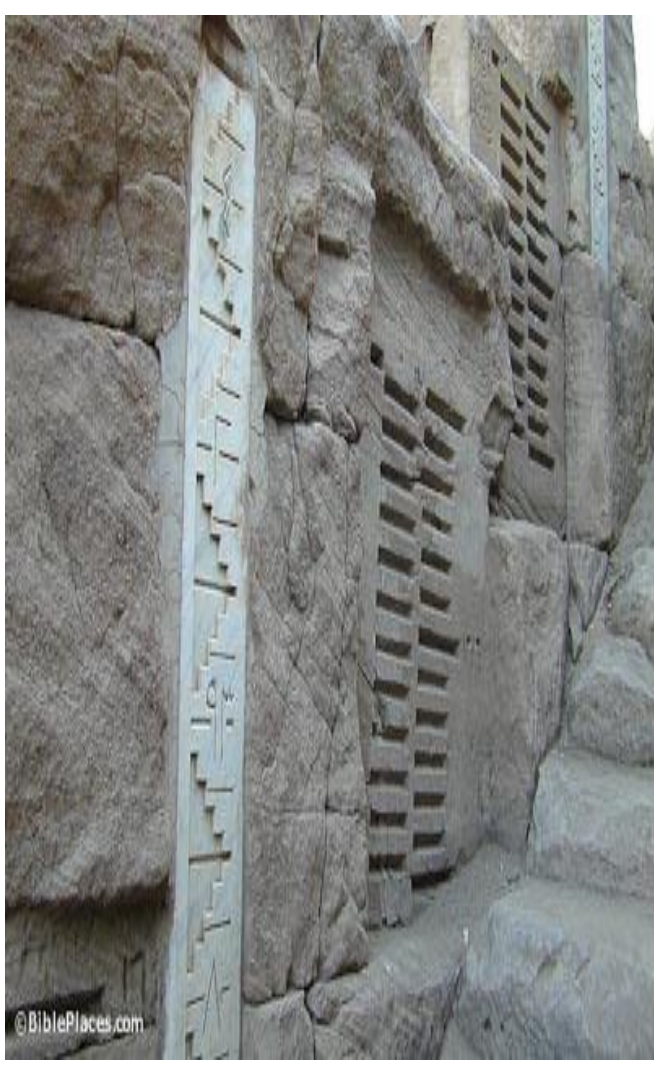

\begin{tabular}{|l|l|}
\hline Level of Overflow & Irrigated Area \\
\hline 10 & 332 \\
\hline 11 & 403 \\
\hline 12 & 480 \\
\hline 13 & 563 \\
\hline 14 & 652 \\
\hline 15 & $?$ \\
\hline 16 & $?$ \\
\hline
\end{tabular}

- Based on the table, is there a pattern between overflow level and irrigated area? Fill in the blanks in the table.

- What benefit did recording overflow levels and crop amounts bring to the people in ancient Egypt? Explain the role of statistics in our daily life. 


\section{Activity 4}

Most of the earliest measurement units were parts of the body. Handspan, foot, hand, digit and cubit were all used by ancient Egyptians and Babylonians as length measurement units. The hand was used by almost all ancient civilizations as a basic measurement unit and is the basis of the unit used today to measure the height of horses. The height of a horse is determined by measuring the distance from the ground to the shoulder of the horse in hands. One hand has been standardized as $10.16 \mathrm{~cm}$. The length measurement unit used 4000 years ago in ancient Egypt was the cubit (the distance between the tip of the middle finger to the elbow). Conversion between units was used in ancient Egypt to measure length.
Egyptian Units of Length (Lumpkin, 1997).
Cubit
The length of a forearm, from elbow to extended fingertips
Palm
The outstretched hand, without the thumb-there are seven palms to one royal cubit.

Finger

There are four fingers to one palm, and 28 fingers to one royal cubit.

As a current measurement unit, 1 cubit may be represented as approximately 52cm (Dilke, 1993; p. 23; Lumpkin, 1997, p. 8-9).

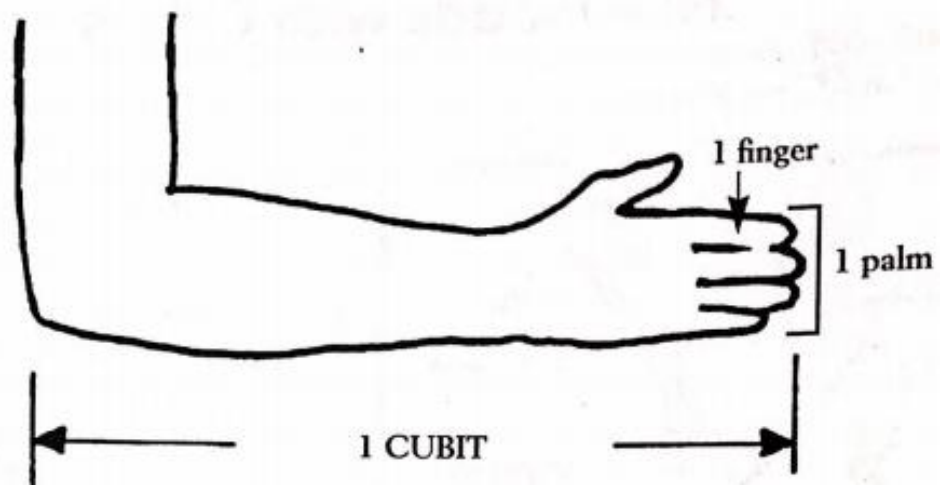

Activity: Understands the importance of using standard measurement units

Learning Area: Measurement

Group: 2 people

Duration: One class hour

\section{Instructions}

(1) Measure the length of different objects around you in finger, palm and cubit. Complete the table below.

\begin{tabular}{|l|l|l|l|l|l|l|l|l|l|}
\hline \multirow{2}{*}{ Objects } & \multicolumn{2}{l}{ Student 1 } & \multicolumn{2}{l|}{ Student 2 } & \multicolumn{2}{l|}{ Student 3 } \\
\cline { 2 - 10 } & Finger & Palm & Cubit & Finger & Palm & Cubit & Finger & Palm & Cubit \\
\hline Desk & & & & & & & & & \\
\hline Notebook & & & & & & & & & \\
\hline Blackboard & & & & & & & & & \\
\hline Map & & & & & & & & & \\
\hline
\end{tabular}

- Are your measurements the same? If not, how do you explain the difference? 
- As shown in the figure above, ancient Egyptians used cubit measurement rods. 1 cubit was approximately 52cm. (Dilke, 1987; Lumpkin, 1997). Design a similar measurement tool to measure length.

- With a friend, measure the length of a desk separately by using a standard measurement unit. What are the results? Explain which measurement units you would choose to use by giving your reasons.

\section{Activity 8}

We can deduce the mathematical thinking style in ancient Egypt from the papyruses. The papyruses are the written sources of those times. One of these papyruses, one that dates back to the 1700s B.C., can now be found in the Moscow Museum and is known as the Moscow Papyrus. It contains 25 problems. The 14th problem on the Moscow Papyrus is about the volume of a truncated square pyramid (height 6, bottom base length 4, upper length 2). Underneath the problem is its step by step solution.

One of the oldest Chinese texts and written around 200 B.C., the book titled Jiuzhang Suanshu explains how to calculate the volume and area of various geometric shapes in its section 5. Jiuzhang Suanshu gives the volume rule for a truncated rectangular pyramid shown below as: $V=$ $\frac{1}{6}[(2 a+c) b+(2 c+a) d] h$
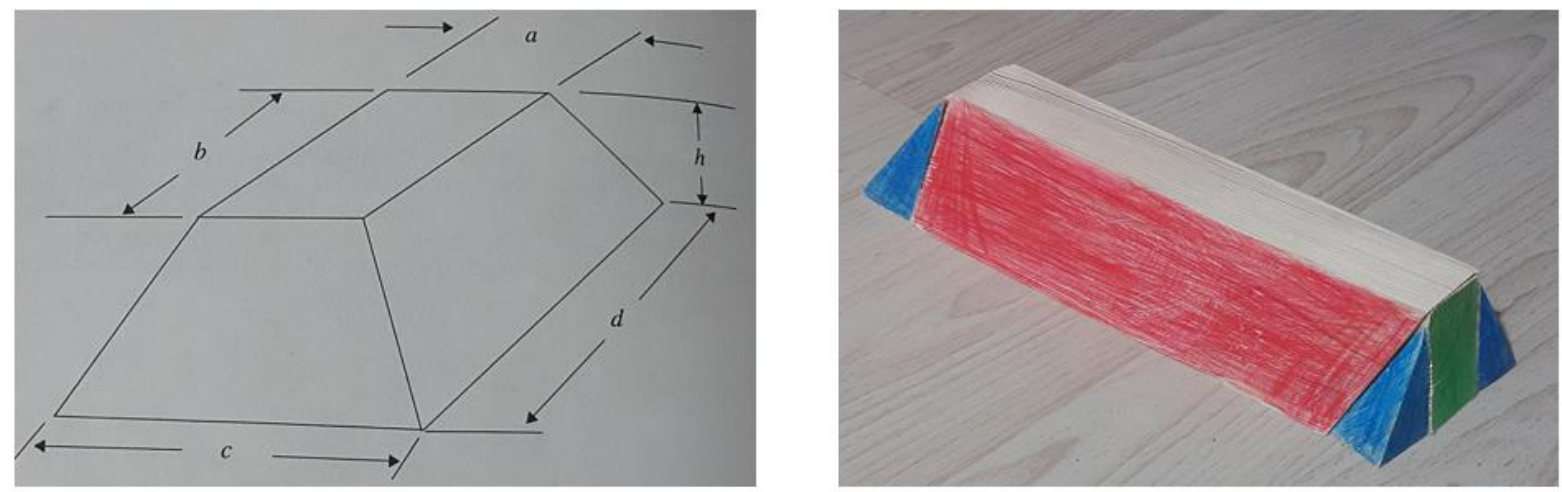

How could the ancient Chinese have found this rule? Try to reach the rule given above by following the steps given below.

Activity: Calculates the volume of truncated pyramids

Learning Area: Measurement

Group: 2 people

Duration: One class hour

\section{Instructions}

(1a) To the right is a truncated rectangular pyramid. Connect the red, green and blue pieces in the pyramid.

(1b) Which geometric figures did you obtain as a result? Write them down.

(1c)Write the volume of each geometric figure as a, b, c, d and h. (The figure above explains what $\mathrm{a}, \mathrm{b}, \mathrm{c}, \mathrm{d}$ and $\mathrm{h}$ refer to).

(1d) Did you reach the rule above when you found and added the volume of each piece? Discuss with your group mate.

(1e)Try to find the rule for the volume of this pyramid via the modern method and compare your results.

(1f)Is the rule used in ancient China to calculate the volume of a truncated rectangular pyramid accurate? Comment. 
(2) The 14th problem in the Moscow Papyrus is, in today's terms: Find the volume of a truncated square pyramid whose height is 6 , bottom base length 4 , upper length 2 . The solution of this problem is as follows in today's terms:

- Square 4,16

- Double 4, 8

- Square 2,4

- Add 16, 8 and 4, 28

- Take one-third of 6,2

- Multiply 28 by 2,56 .

- $\quad$ The volume is therefore 56 .

Study the underlying meaning of the solution.

\section{Activity 9}

The ancient Chinese Jiuzhang Suanshu (206 B.C.- 220 A.D.) wrote the long form of $(a+b)^{3}$ in a unique way. The method uses the volumes of the geometric objects given below. Use the objects below to write the long form of $(a+b)^{3}$. It's your turn.

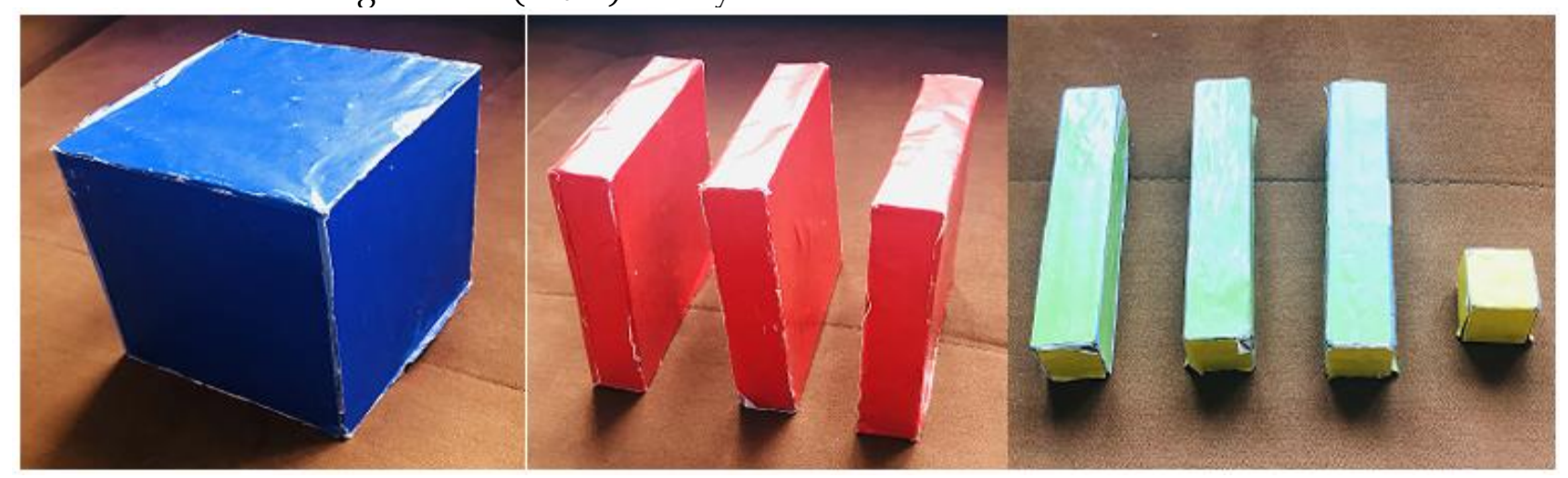

Activity: Writes the long form of $(a+b)^{3}$

Learning Area: Algebra

Group: 2 people

Duration: One class hour

\section{Instructions}

(1) The blue object is a cube with length $a$; the red object is a square prism with base length $a$ square and height $b$; the green object is a square prism with base length $b$ square and height $a$; and the yellow object is a cube with side length $b$.

(2) Combine these geometric figures appropriately to obtain a cube with side length $a+b$ units.

(3) How do you find the volume of a cube with units $a+b$. What kind of a relationship exists between the volumes of the pieces that make the geometric shape you obtained and the volume of the cube with $a+b$ units? Write the long form of $(a+b)^{3}$ by considering this relationship. 


\section{Activity 10}

Carl Friedrich Gauss (1777-1855) is one of the greatest mathematicians of all times. He was born in Germany to a poor and uneducated family. Known also as the 'prince mathematician' and the 'greatest mathematician since antiquity,' Gauss was a naughty student who chattered throughout classes. One day, his teacher asked him to add all the whole numbers from 1 to 100 to keep him busy. Gauss did the sum within seconds and amazed his teacher. He did this by writing the whole numbers from 1 to 100 side by side, and then pairing 1 with 100, 2 with 99 and so on. He then added up the paired numbers, divided the sum into two and reached the sum within seconds. How about replicating Gauss' solution with unit cube models? Follow the instructions below to solve the problem.

Activity: The sum of consecutive positive whole numbers

\section{Learning Area: Algebra}

Group: 2 people

Duration: One class hour

\section{Instructions}

(1) Below are the models that belong to the consecutive positive numbers $1+2+3+4+5$. Take note that the number $\mathrm{n}$ in the models equals 5 .

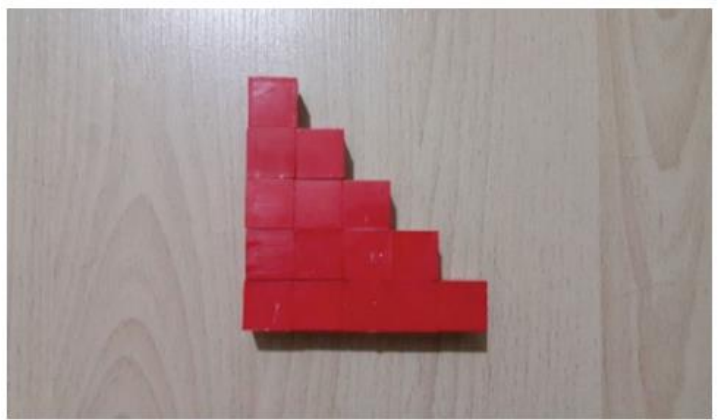

(2) Think about Gauss' solution and ways of combining the model below with the shape above. Explain the geometric shape you obtain as a result. (Students are given rectangles on dotted paper, and the side lengths are shown as $\mathrm{n}$ ).

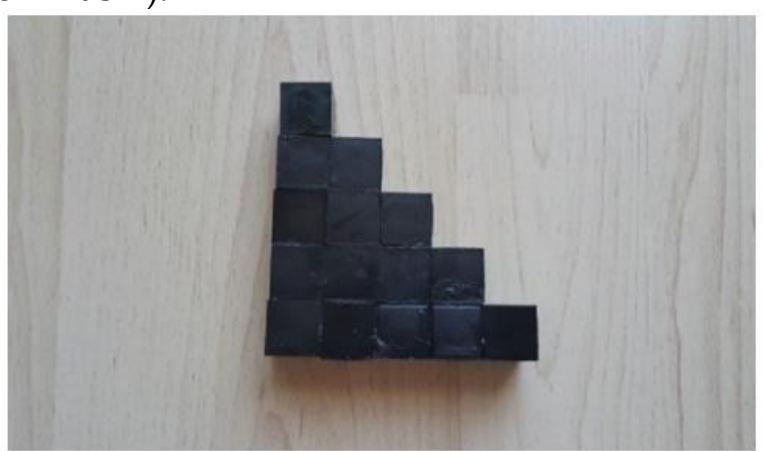

(3) Based on the geometric model you obtained, state mathematically the rule used to reach the sum of the numbers from 1 to $\mathrm{n}$. Solution: When two models representing consecutive positive integers are combined as in the figure, a rectangle with side lengths $5 \mathrm{br}$ and $6 \mathrm{br}$ will be obtained, as shown in Figure 3. With $n=5$, the area of the rectangle equals two times the sum of $1+2+3+4$ +5 . If $1+2+3+4+5=S$, n. $(n+1)=2 S$ yields $S=n \cdot(n+1) / 2$. 
Appendix 11. Work by teacher candidates
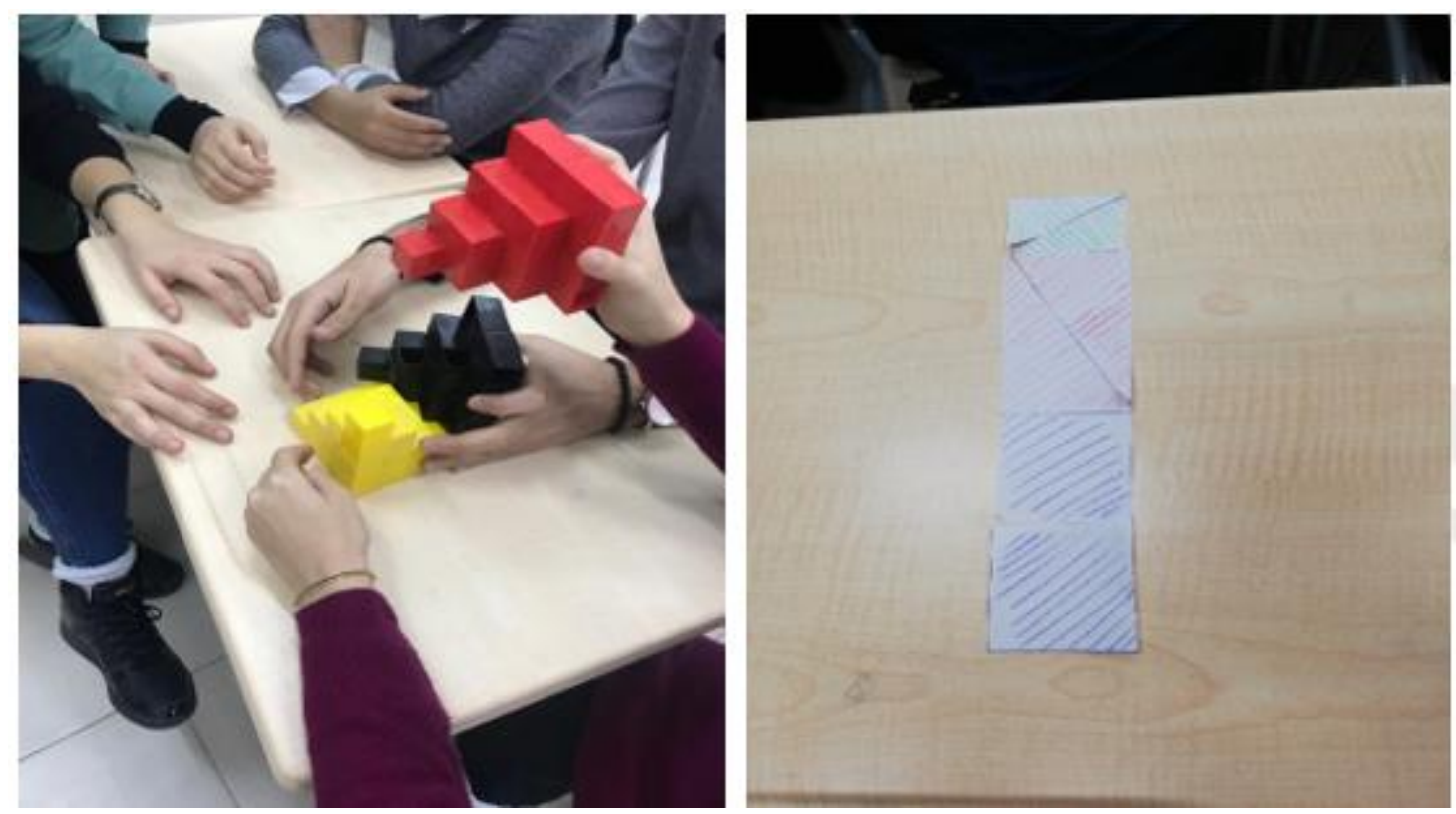

Activity 5 (The solution of similarity problems with the cut and divide method in ancient Chinathe right) and Activity 11 (The rule for the sum of square numbers in ancient China-the left) by teacher candidates
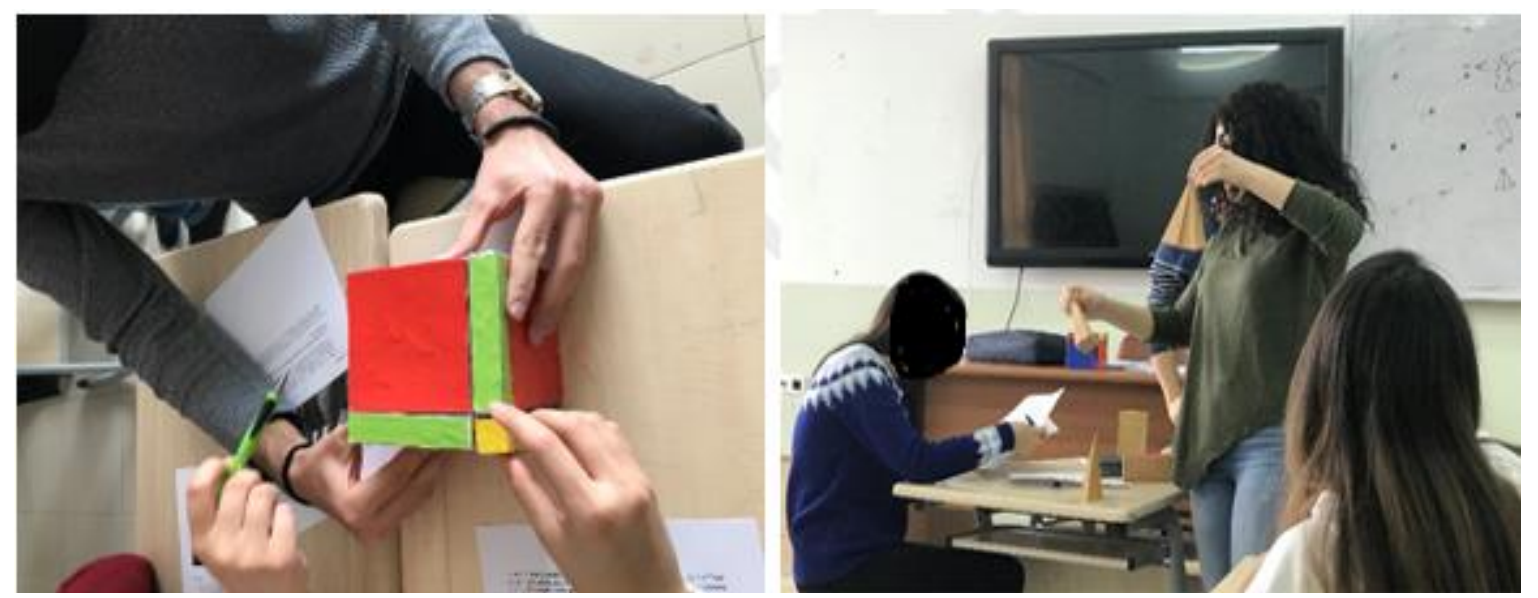

Activity 9 (The long form of $(a+b)^{3}$ in ancient China-the left) and Activity 10 (The volume formula for truncated square pyramid in ancient Egypt-the right) by teacher candidates 